\title{
ظهور الإلحاد وتطوره في ضوء القرآن الكريم
}

زياد اسماعيل حمد، كلية العلوم الاسلامية / قسم أصول الدين. zyadxorane@gmail.com saman.afryani@gmail.com سامان أحمد رمضان: كلية العلوم الاسلامية

الماخص

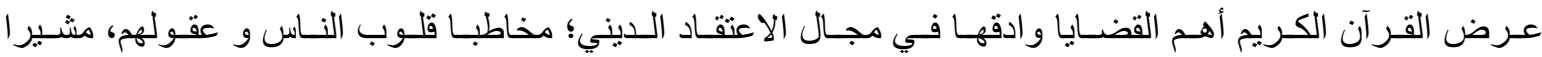
إلـى فكرة الملاحدة و الملحدين؛ فيمـا يتعلق بكل مـن الإلحساد و الانحـر اف عن آيـات الله تعـالى، و الإلحساد في أسـمائه؛ وقد تنـاول هذا البحث العلمـي هذه القضية مركز ا على نبذة قلبــة مـن ظهور هذه الأفكار و انتشـار ها في وسط ذوبي الميول الإلحاديـة، وبـو ادر هـو لاء التيـار ات الـائرة في فلكهم منهـا رائحسة الإلحـاد، مسـلطا الضـو ع على كيفيـة نشـأة هذه الأفكار

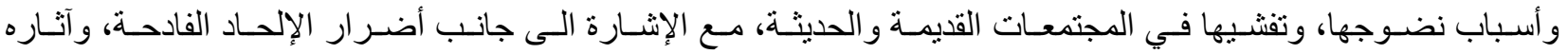

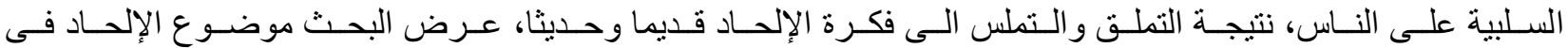
المجتمعـات الغربيـة فـي العصـور المظلمـة حتـى عصـر التنـوير، والمجنــع الإسـلامي، حيث أن الإنكـار المتعلـق بوجـود

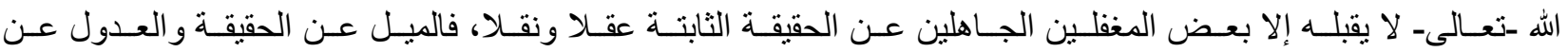
المقاصد المعقولة هرطقة و إلحاد وخروج عن الدين، وهذا هو هدف البحث. بهن.

\section{المقدمة}

الحمد لله رب العالمين، الذي منَّ علينا باز احتنا عن طريق الملددين، حمدا دائما إلى يوم الدين، و الصلاة والسلام على سيد الأنبياء و المرسلين، و على آله وصحبه و التنابعين لهم بإحسان إلى يوم الدين. وبعد .....

فإن خير ما جعلنا لنا الاسلام للسير عليه هو المنهج الرباني والثريعة السمحة الني أمرنا الله -تعالى- بها، والسمع

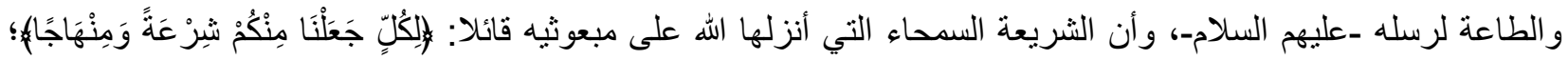
(سورة المائدة، 48/5.) هى الدعوة إلى الإيمان بالله - تعالى- و الابتعاد عن إذلال النفس لغير الله -عز وجل-، وأن نؤمن

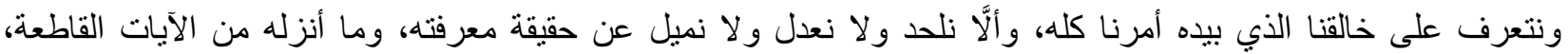

$$
\text { و البر اهين الساطعة، والحجج الباهرة على أنبيائه ورسله (عليهم السلام). }
$$

وفي هذا المقام يحسن بنا الوقوف على محاولات التحريف والتغيير و التزييف للحقائق التي إنَّـــــأ عليها الملاحدة، وكهنة الأفكار المصنوعة، ولاهوتيو الأديان المحرفة؛ لإفساد الدين الحق؛ لمن جهة أن فكرة عدم الإيمان بالله، أو العدول عن الحقائق الإيمانية لكل دين من الأديان السماوية أمر خطير في غاية الخطورة على الإنسانية جمعاء، فيحيد بنا عن نطوير الحياة الروحية، ويبعدنا عن طريق معرفة خالقنا (جل و علا).

$$
\text { أسباب اختيار الموضوع: }
$$




$$
\text { أرََّّبة الدَّائمة في الإهتمام بعلم التفسير ، والبحث عن مسائله، وموضو عاته. }
$$

الإطلاع على معلومات ذات الصلة بفكرة الملاحدة، وفكرة إنكار وجود الله تعالى، و كيفية نشأة هذه الفكرة.

و أريد بهذا البحث على الاقل إملاء جانب من هذه الثغرة المخفية، و زيادة الفائدة وتوثيق المعلومات من خلال مطالعة

$$
\text { المصادر والمر اجع التّي تعنمد عليها. }
$$

$$
\text { الصنُعوبات: }
$$

البحث عن هذه الفكرة المخفية ومحاولة الوصول إلى حقائقه يُعدّ أحد أنواع الصّّعوبات، التّي يتلقّاها الباحث أثناء بحثه؛

$$
\text { لأنَّ الموضوع يحتاج إلى اطلاع واسع على المصادر المتعلّقة بها. }
$$

قلة المصادر و المر اجع حول الموضوع في علم التفسير، وجمع الأرآه و الأقوال وحصره مما يصعب المهمة على الباحث ويتطلب مضاعفة جهده.

$$
\text { و نرجو من الملك المنان أن بتقبلنا بقبوله و الامتنان بفضله و جوده. }
$$

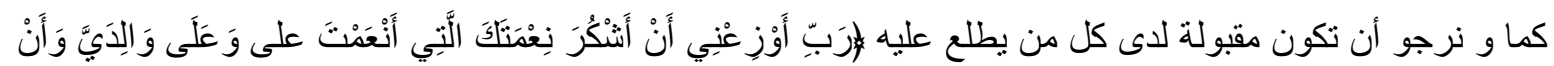

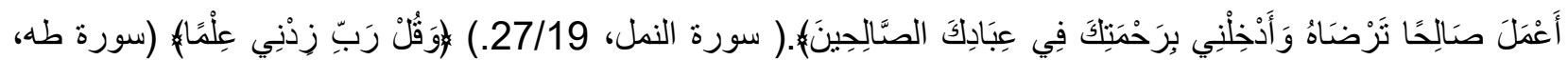
101/12. 114/20.

وصلى الله على سيدنا محمد و على اله وصحبه وسلم أجمعين

$$
\text { و آخر دعو انا أن الحمد لله رب العالمين }
$$




\section{المبحث الاول: نشأة الالحاد وانواعه واسبابه}

الإلحاد له معنى واسع في نطاقه المسموع، واستعماله الثائع بين جميع الأفكار، وكذا إطلاقه على بعض الجهات و الأشخاص المؤيدين لبعض الأفكار المستوردة من قِبِلِ الثخص الملحد، أو المنظمات المزيفة للأفكار البعيدة عن الحقيقة العلمية؛ لذا علينا أن نتطرق أولا إلى معنى الإلحاد من جهة استعماله لدى التاريخ، وكذا ما يتعلق به من ألفاظ ذوات الصلة بالإلحاد من مر ادفتها ومدلو لاتها لكي يتضح المعنى أكثر ، وتوضيح التسميات بشكل أكثر جلاءً.

فالإلحاد في مفهومه و اسع، و أوصافه متداولة بين الناس ومتفارق بين الحضار ات؛ لذا قد يفهر من استعمالها إنكار وجود إله للكون الطبيعي وخالق له، وقد يوصف بالإلحاد كل من خرج على عقيدة قومه بالنسبة لله ـ تعالى-، وتختلط بالإلحاد ثلاثة

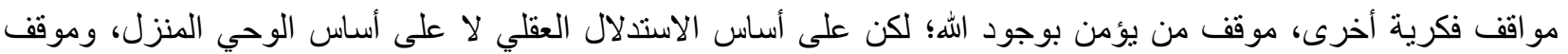

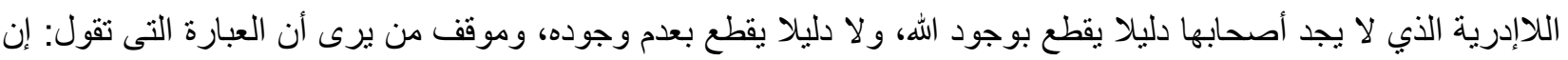
الله موجود أو غير موجود لا تتو افر فيه الخصائص المنطقية التى تجعلها ممكنة التحقيق، فلا هي بالعبارة الصادقة، و لا هي بالعبارة الكاذبة، ولا يلزم عن هذا القول الأخير إنكار وجود الله، إذ قد بأتي إثباته عن طريق الوجدان أو الحدس المباثر.

\section{المطلب الاول: تعريف الالحاد \\ أولاً: الإلحاد في اللغة}

الإحاد إما مصدر مأخوذ من فعل ثلاثي مزيد فيه بحرف "ألحد، يلحد، إلحادا"، و هو مأخوذ من فعل ثلاثي من مادة

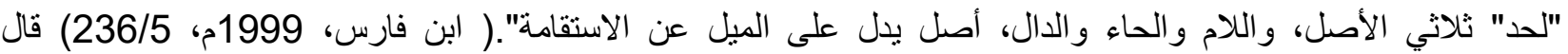
الر اغب: " ألحد فلان، مال عن الحق، ولحد بلسانه إلى كذا مال"، ( الأصفهاني، 1426هـ، 737) و الجمع: ألحاد ولحود، وقد

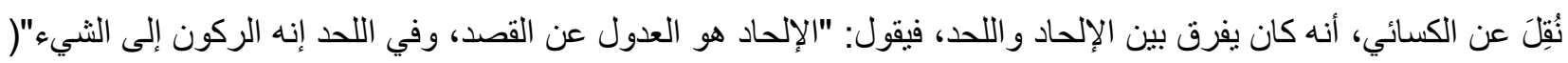

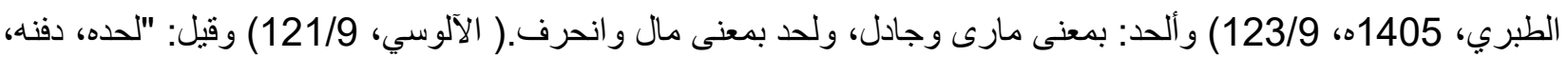

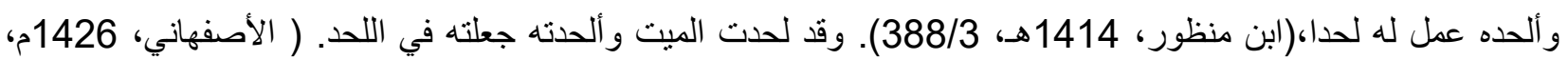
737) ويقال: لحد السهم عن الهدف عدل عنه، وإليه مال.( مصطفى، والزيات، 817/2) ويقال: قد ألحد فى الدين؛ أي حاد عنه و عدل،( زين الدين الرازي، 1999م، 247/1؛ ابن منظور، 1414 هـ، 388/3.) وفي الدين طعن، فالملحد الطاعن في الدين، المائل عنه، وجمعه ملحدون وملاحدة،( إبر اهيم، والزيات- 817/2) و هو الأصل في" الإلحاد" و ألحد في الدين حاد عن ولن

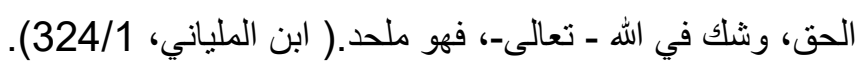

وباللغتي الانجليزية والفرنسية يطلق على كلمة الإلحاد (Atheism) بمعنى رفض الدين، وكأن الله غير موجود. (العلايلي، 1947م. إذاًالإلحاد في اللغة، هو الانحراف عن الوسط، والميل عن القصد، أو العدول عن الثيء. 
وللإلحاد أضداد كثثرة وكلمات جمة تخالفها في المعنى اللغوي، وبعكسه في المعنى الاصطلاحي، فكل من كلمة،

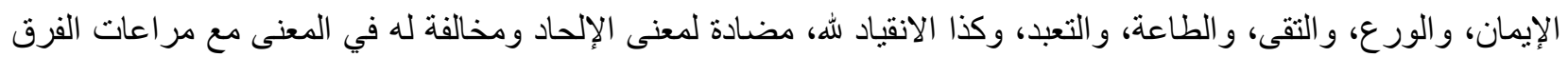
بين التضاد والاختلاف، ونتناول فيما يأتى تعريف كل من الكلمات المضادة لكلمة الإلحاد: 1-الإيمان:هو مصدر آمن يُؤمن إيماناً؛ فهو مُؤمن، واتفق أهل العلم من اللُّغوين وغيرهم أن "الإيمان" معناه،

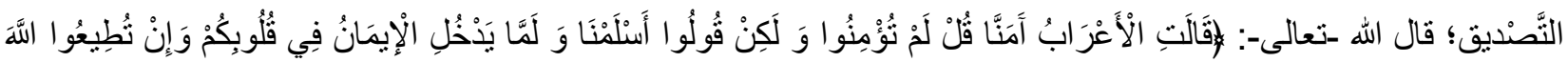

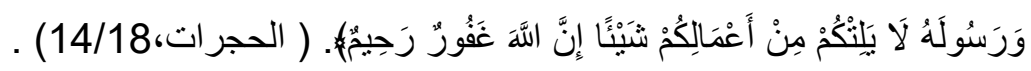

ويقول الراغب: " استعمال آمن، إنما يقال على وجهين: أحدهما: متعديا بنفسه، يقال: آمنته، أي جعلت له الأمن، ومنه قيل اله: المؤمن، والثاني: غير متعد، ومعناه، صار ذا أمن"، (الأصفهاني، 1426م، 48/1). وقيل: إن الإيمان: هو الثقة و إظهار الخضوع وقبول الثريعة. (الفيروز آبادي، 1518/1).

2- الوَرَع: الو او والراء والعين، "أصل صحيح يذل على الكف والانقباض، منه الورع، والعفة وهي الكف عما لا

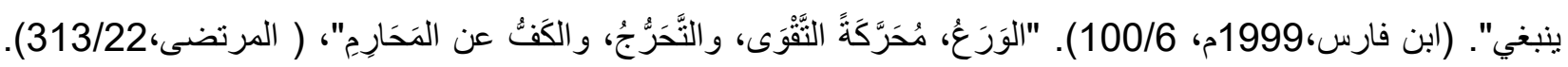

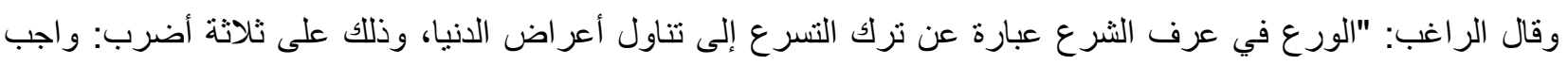

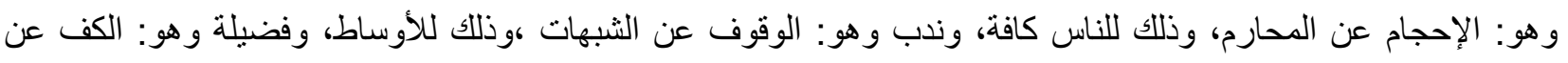

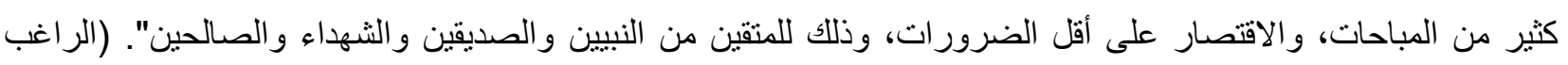
الأصفهاني،2007م، 227).

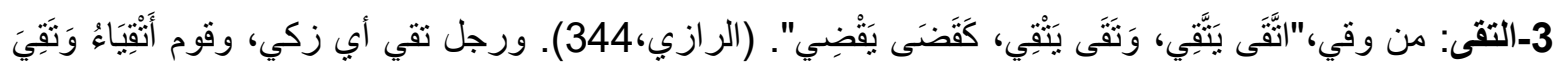

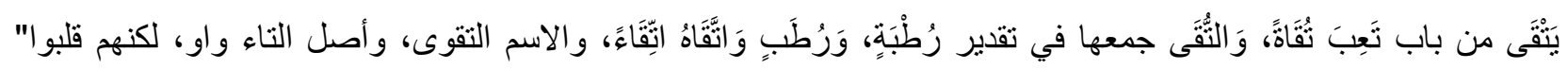

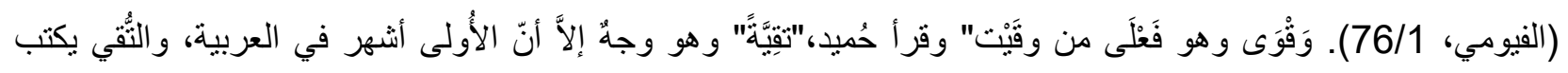
بالياء. (الأزهري،1399هـ، (6) 200/9).

وذهب المناوي بأن التقوى هي: تجنب القبيح خوفا من الله، وأصلها الوقاية، وعند أهل الحقيقة، هو التحرز بطاعة الله عن عقوبته، وهي صيانة النفس عما تستحق به العقوبة. (المناوي، ودي، 1990م، 199). وقال الجرجاني، "التقوى في الطاعة يراد بها الإخلاص، وفي المعصية براد به الترك و الحذر، وقيل: المحافظة على آداب الثريعة، وقيل :مجانبة كل ما يبعدك عن الله -

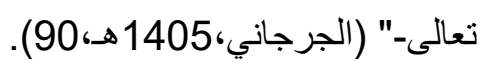

أما الفرق بين التقوى والتقى، قيل: التقوى خصلة من الطاعة يحترز بها من العقوبة، والتقى، صفة مدح لا تطلق إلا

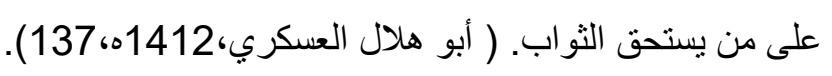

4-التَعَبُّ: من عبَّ يعبُد عِبادة، فلا يقال إلا لمن يعبد الله "وتعبَّد تعبُّداً، أي تفرّد بالعبادة " (الفراهيدي، 2/ 48). فالعين

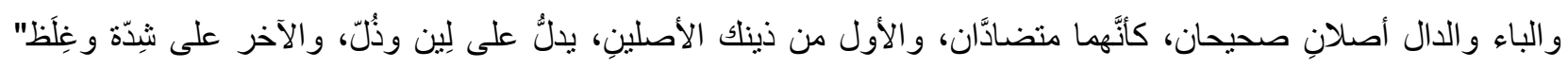

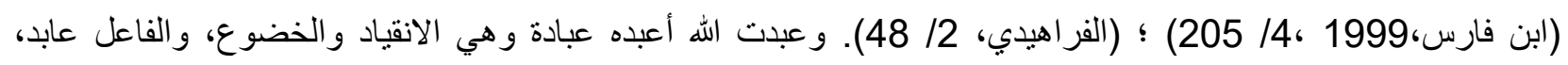

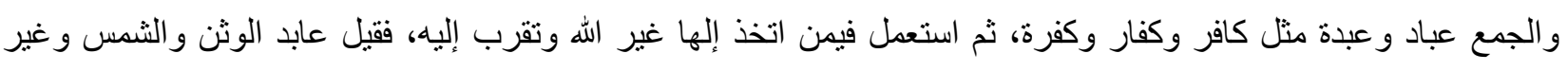

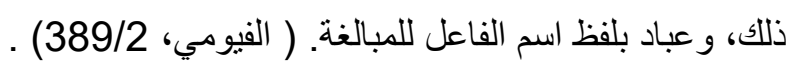


اذاً العبادة، هو فعل المكلف على خلاف هوى نفسه؛ تعظيمًا لربه، و العبودية، الوفاء بالعهود، وحفظ الحدود، والرضا

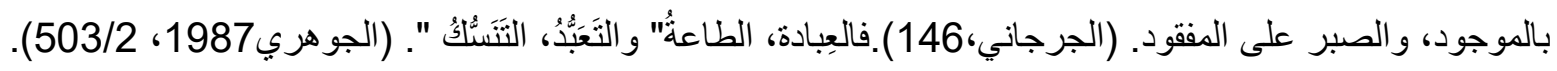
5- الطاعَة: لغة، الانقياد و الموافقة، يتعدى بنفسه ويتعدى بالحرف، فيقال: أطاعه إطاعة،أي انقادله، ويقال، طاع له، و الاسم، طاعة، وأنا طوع يدك،أي منقاد للك، و الفاعل من الثلاثي، طائع، طيّع، و الفاعل من الرباعي، مطيع.

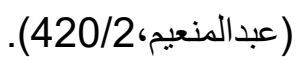

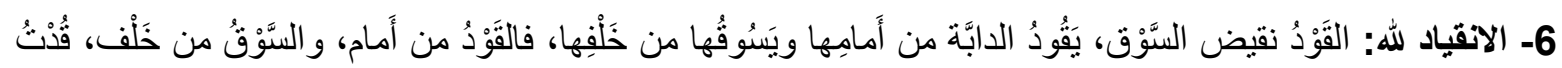

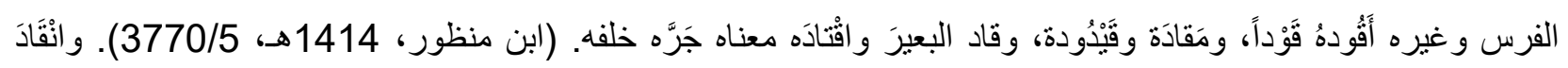

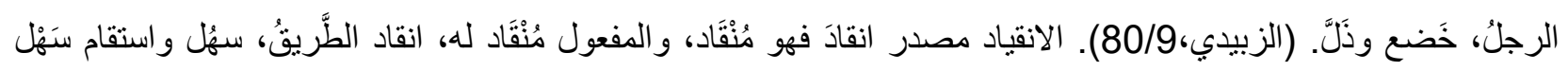

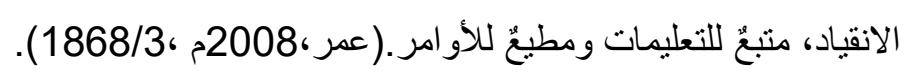

فالانقياد والخضوع لدين الله لا يحصل الا بالتسليم التام؛ لهذا الدين في أصوله، فخالفته تحصل بإحداث أصول

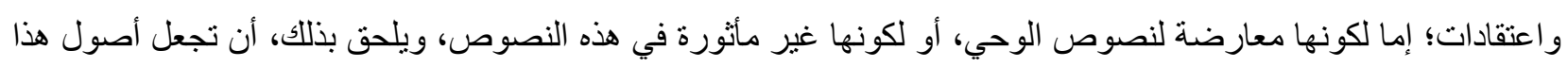
الدين محل جدل وخصومة مما يفضي - في الغالب - إلى الاعتر اض عليها، لذا وقد يفسرون معنى الاسلام بالانقياد لأوامر الله فمفهومه المخالف هو الكفر والإلحاد، فالبارى جل في عليائه أثار في القرآن الكريم بما يناسب أهل الكفر والإلحاد، وما بليق

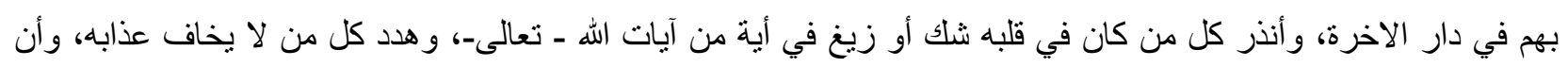

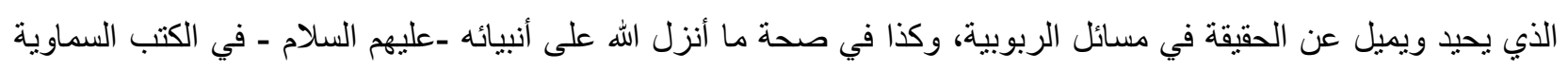
وما أنزل الله - تعالى- عليهم بالسلطان المبين، فكل من جحد وأنكر الآيات الباهرة والحجج الدامغة فقد ينال العقوبة من اللهـ

\section{ثانياً: الإلحاد في الاصطلاح}

تطلق لفظة الإلحاد أو"الملحد" في الاصطلاح على كثير من الطاعنين أو الثاكيّن في الله أو في الدين، وله ألفاظ كثيرة منر ادفة مع معناه، ومتقاربة منه في العربية وغير ها من اللغات، كإطلاق مصطلح" الدهرية، و المانوية، والمادية، والباطنية، و الزندقة"؛ لذا عرفت بتعريفات عدة، منها.

قال: (علي بن طلحة) عن ابن عباس: الإلحاد، التكذيب،(ابن كثير، 2006م، 107/9). و عنه - أيضا- : الإلحاد، هو

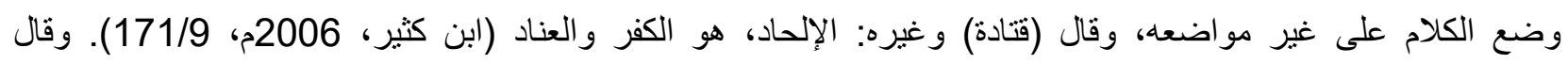

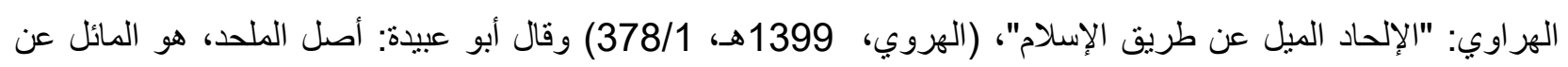

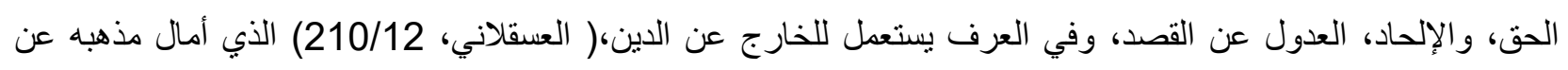

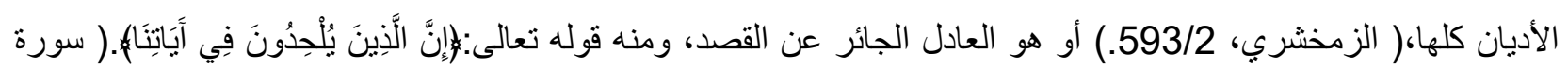
فصلت، 40/41) أي يجورون ويعدلون. 
ولا يشترط في الإلحاد الاعتر اف بنبوة محمد- علموسلله - ولا بوجود الله -تعالى-، وبهذا يختلف عن الدهريين؛ ولا إضمار الكفر، و به فارق المنافق؛ ولا سبق الإسلام، و به فارق المرتد، فالملحد أوسع فِرق الكفر حدا، أب هو أعم من الكل. (سعدي،

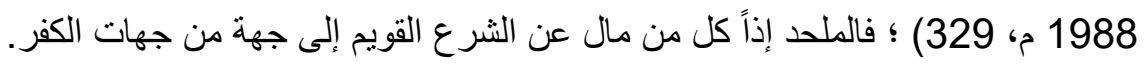

\section{ثالثا: مسميات الملحدين بين الماضي والحاضر وتطورها}

ذكر فيما سلف تعريف لكلمة الإلحاد الثائع وهو المر اد هنا؛ ولكن بستعمل الكثير من المصطلحات القديمة والحديثة على هذه الفئة والأشخاص المعتنقين لفكرة الإلحاد والملاحدة، مثلالباطنية، قال بعض الأئمة: "و الملحدون في زماننا هم الباطنية، الذين يدّعون أن للقرآن ظاهرا وباطنا، وأنهم يعلمون الباطن فأحالوا بذلك الثريعة؛ لأنهم تأولّلوا بما يخالف العربية التي نزل بها القرآن".( الفيومي، 550/2.

1 - اطلقت كلمة الملاحدة عن من سمّو الباطنية؛ لادعائهم أن النصوص ليست على ظو اهرها بل لها معان باطنة لا

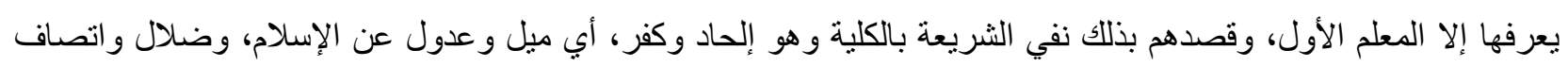
بكفر ؛ لكونه تكذيبا للنبي-عمليسلمه.--( التفتاز اني، 1374هـ ، 247.) كما يقول: (أبو منصور الهروي) "وملحدو ازماننا هذا هؤلاء الذين تلقبوا بالباطنيه، وادعوا أن للقرآن ظاهرا وباطنا، وأن علم الباطن فيه معهم؛ فأحالو ا شرائع الاسلام بما تأولوا فيها من

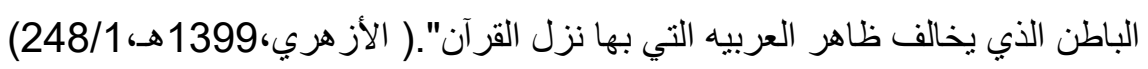

2 - يستعمل مصطلح "المانوية"، وهم فرقة من الثنوية أتباع ماني بن فاتك الحكيم، الذي ظهر زمن سابور بن أردشير في القرن "الثالث ميلادي" قتلك بهر ام بن هرمز بن سابور، أحدث دينا لقَََّهُ من المجوسية و النصر انية، فال: بأن العالم مكوّن

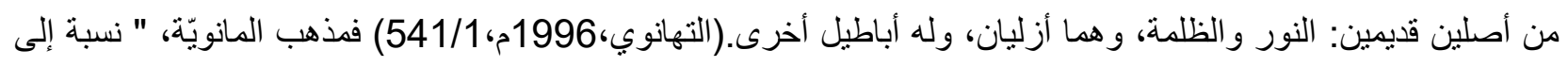

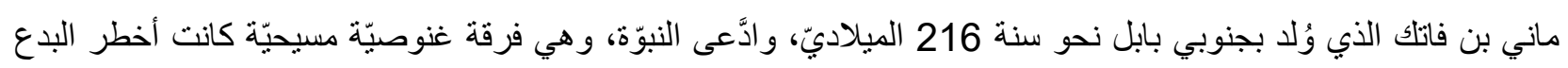

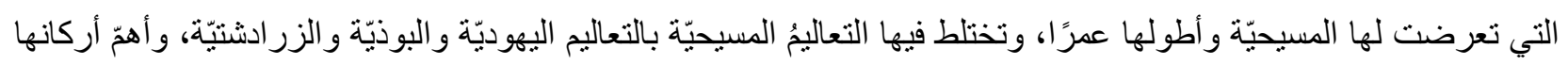

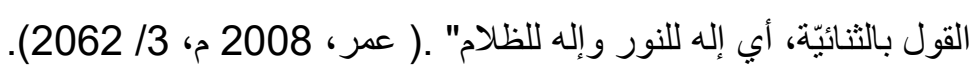
3 - يطلق على الملحدين مصطلح "الزندقة" أو "الزنادقة"؛ لأن الزنديق هو أن لا يؤمن بالآخرة ووحدانية الخالق،

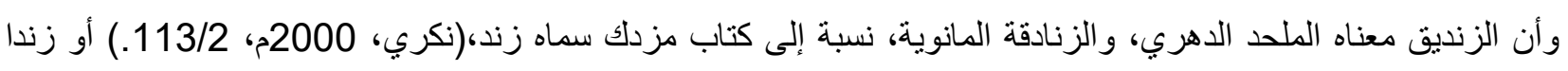

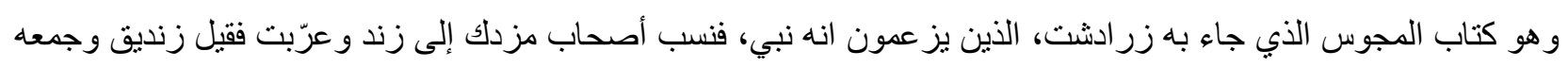

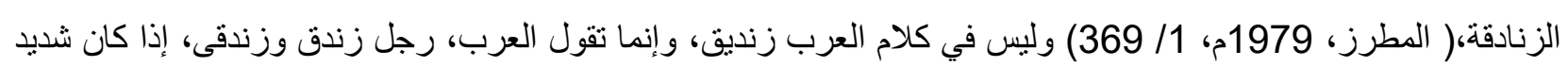

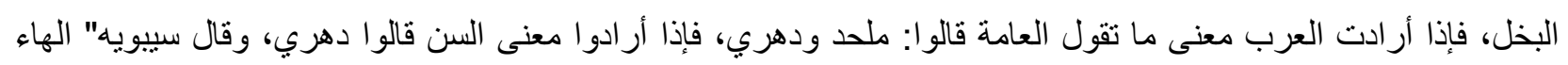

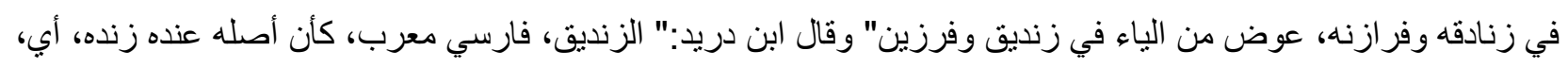

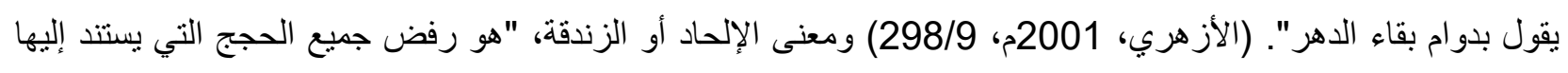
المفكرون في التدليل على وجود الله، وكأن الله غير موجود".( العلايلي، 1947م.

4 - تطلق اصطلاح "الاهريين" على الملحدين، وهو مصطلح مشتق من الدهر، يطلق على من يقول بقدم العالم، أو أن

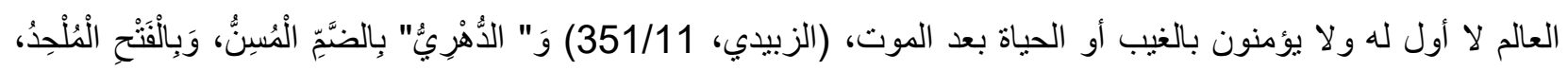

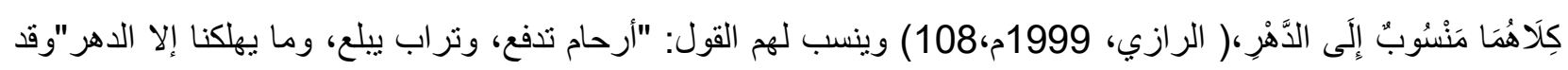




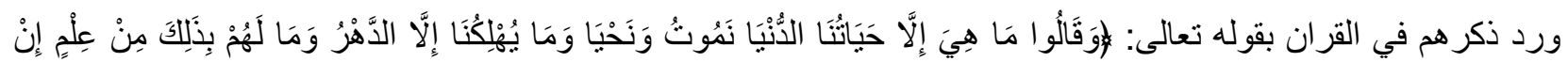

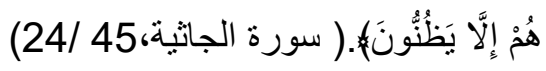

5 - تستعمل كلمة"المادّيين" على الملحدين، هم الذين ينكرون النبوات والرسالات السماوية، كما أنهم ينكرون وجود الإله ـ تعالى- و لا يعترفون بوجوده. (عليان، وقحطان،2004 ،204) واعتقدوا أن الكون كلها مادة، وتلك الكون تتكون من ذرّات، والذرّات لا أول لها، وتطورت الماديّة الجدلية أو الماديّة الدياليكتكية الجدلية نطورا سريعا غير متوقع على أيدي ثلاثة فلاسفة، هم بحق أبطال الفلسفة الماركسية وبناة أساسها الاعتقادي أولهم: كارل ماركس(1818- 1883) ثانيهه: فريدريك انكليز(1820- 1895) وثالثهم: فلاديمير ايلتشن لينين(1870- 1924).( نصري، 2000م، 38). و وأطلق الإلحاد على نفاة

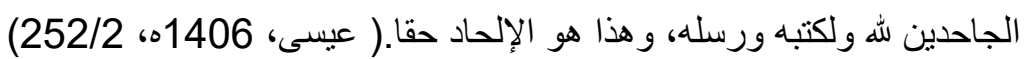

نلخص مما سبق إلى أن الإلحاد أو الملحدون فرقة يمكن أن نقول: بأنهم شرذمة قليلة ظهرت بين المجتمعات الإسلامية وفكرتهم شائعة بين المجتمعات الأوروبية؛ حيث إن هذه الفكرة موجودة في الكثير من الكتب والصحائف المنشورة فيما يتعلق بالبحث عن الحقائق العلمية، لذا هذه الفرقة يطلق عليهم الكثير من الأسماء المتداولة و الثائعة فيما دوّن من المصطلحات؛ لأن الإلحاد ظاهرة قديمة ظهرت منذ القدم في جميع المجتمعات، وهم قلة قليلة بين الأفراد، ومن المعلوم أن فكرة الإلحاد لا تقوم على دعائم أو أسس، و إنما هي نانئة عن عدم الفهم الصحيح؛ لذا نجد الإلحاد بأنواع مختلفة من حيث الفكرة، فنجد بعض لهض

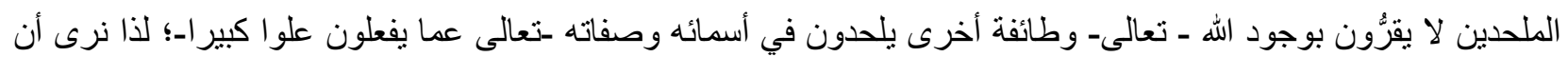
محاربة هذه الفكرة يجب أن تكون على علم ثبوتي، واستدلالات عقلية معقول؛ لكي نرفض ما يعتقده الملحد وما ينكرونه ويضادونه من شرع الله.

\section{المطلب الثاني: تاريخ نشأة الالحاد}

لقد كان الإلحاد بكل متر ادفاته ومعانيه كان موجودا في الحضار ات السابقة؛ لذا فان كثير ا من الأدباء و الفلاسفة قد نسب

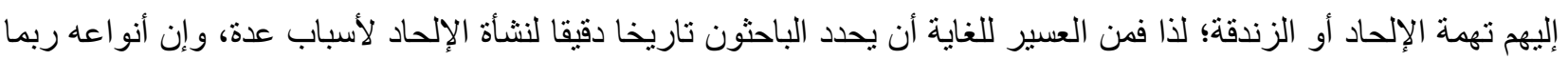
تكون واحدة بحسب الفكرة و العقيدة، أما أسبابه فقد تكون تختلف من مكان إلى مكان آخر ، ومن زمان إلى زمان آخر.

\section{اولاً: أسباب نشأة الإلحاد}

الأسباب التي أدّت إلى نشأة الإلحاد كثيرة منها: أن معنى الإحاد لا يتسم بالوضوح الكافي، فضلا عن أن معناه في

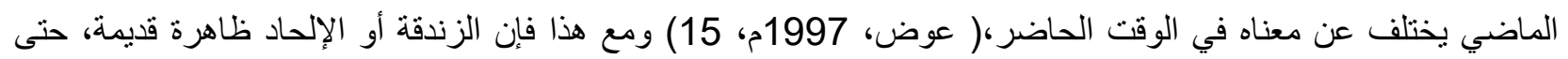
فبل ظهور المسيحية اتهم الإغريق عددا من فلاسفتهم وأدبائهم ومفكريهم بالهرطقة، وهي الخروج من مبادئ الكنسية، فمنهم الفيلسوف"سقراط" الذي حكم عليه بالموت بشرب السّم عام (399 ق-م) وكذا النحاتفيداس ( 500ث-م) وهئم والكاتبيوربيديس (470ة-م) اتهمو هما بالهرطقة، و عاقبو هما عليها،(عوض، 1997م، 15) ولعل أول هذه الحركات المسجلة تاريخيا للإلحاد في الهند تقريبا عام 1000ق-م، حيث كانت أول علامات الثك في النص المكتوب" Rig-Veda" الفيدا كتب الهندوسية القديمة الدينية الأربعة، وبعد 500 عام ق-م، ظهرت البوذية، وحاول بوذا في( 483 - 563ق-م) أن ينقل الفكر على التركيز

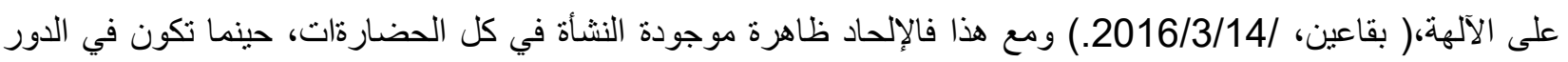
المدنية، وإنها نتيجة لازمة لحالة النفس التي استتفدت كل إمكانياتها الدينية، فلم يعد في وسعها بعد أن تؤمن،( البدوي، 1993، 
7) كما هي الحال في حوالي عام430، ق-م، ظهرت النزعة المادية في اليونان في القارة الأوروبية، وبدأ مبدأ الذرّات على دهى يد" ديموقريطس" الذي ألغى بنظريته وجود الآلهة في عالم مادي بحت، وكذا" ابيقور" في القرن الرابع الذي يعتبر أول

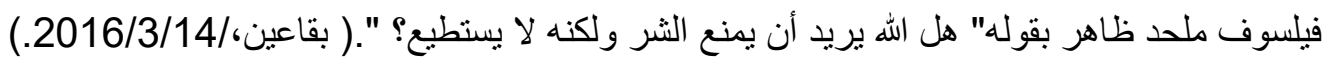

\section{ثانيا: نشأة الالحاد في الغرب}

على الرغم مما ذكرنا من نشأة تاريخ الإلحاد في هذه المرحلة فانه لبس هو بالإلحاد الحقيقي، ويعد الإلحاد بدعة جديدة لم توجد من قبل في جاهليات التواريخ السابقة أو القديمة إلا في النادر في بعض الأمم والأفراد، بمعنى أنه لم توجد بهذه

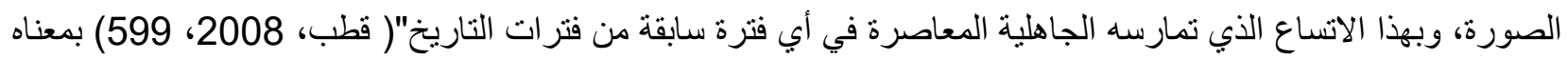

المعاصر.

وفي حدود البحث نذكر بعض النماذج التي أدت إلى نشر الإلحاد ونشأتها وجذوره التاريخية، ويمكن القول: إن العودة إلى الحضارة الإغريقية الجاهلية الوثنية هي من الأسباب التي أدت إلى ظهور الإلحاد، وكذا العودة إلى الحضارة الرومانية

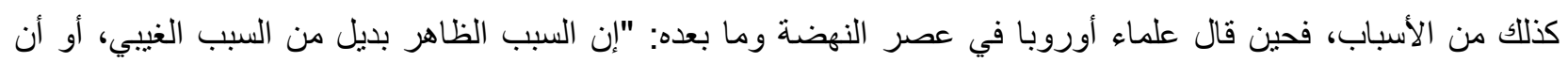
الطبيعة بديل عما وراء الطبيعة، أو جعل أوروبا الطبيعة بديلا من الله"( قطب، 2008، 621 - 622) فتبدأ نشأة فكرة الإلحادمن هنا كما يعتقد الباحث.

في نهايات القرن السابع عشر، وبدايات القرن التاسع عشر، ومع التطور العلمي والتكنولوجي وبما شهده الغرب من

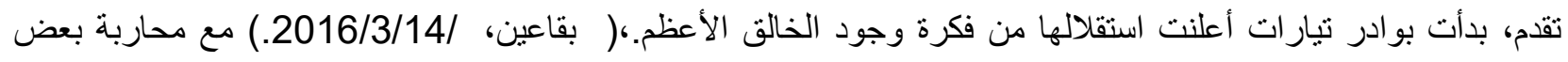
الجهات لهذه الفكرة، فلأول مرة في عام 1574 م، نم تنفيذ حكم الإعدام في أحد نبلاء أورليانز، بفرنسا اسمه" جيوزوي فالئ فاليه" نتيجة نبذة ألّها وأنكر فيها وجود الله، وتم إحراق جسده مع النبذة التي نشرها، باستثناء نسخة واحدة، ومن الجدير بالذكر أنه انتشرت في فرنسا بعض المخطوطات الإحادية في منتصف القرن الثامن عشر ، واحتوت هذه المخطوطات على ترجمة لكفرة

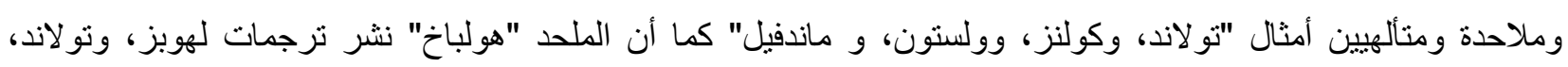
وولستون دانيت". (عوض، وضكا، 1997م، 15- 23) ولكن هذا لا يمكن أن تؤدي نشر الإلحاد بين الجماهير، و إنما الذي نشر الإلحاد

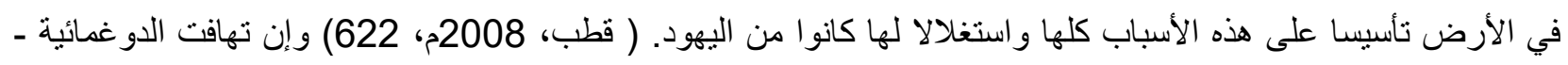
أي المتعصبة - الكنسية إزاء حقائق العقل العملي، يظهر بأنه هو الذي قاد الإلحاد في الغرب، خاصة في في عصر النهابنة وبالأخص في عصر التنوير. والتنوير (Renaissance)، ظهر فى القرنين السادس عشر والسابع عشر تعبيرا عن الفكر

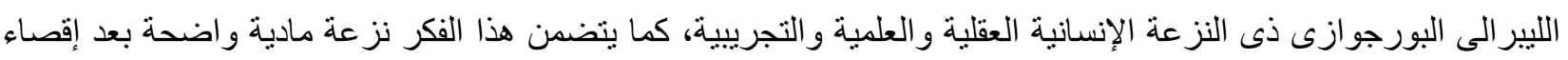

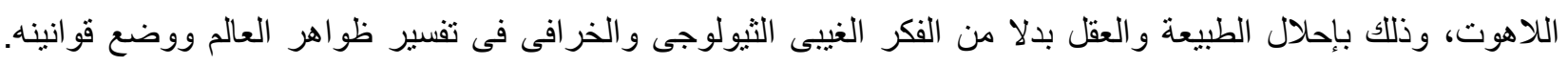
وأطلق على هذا العصر القرنين،السادس عشر والسابع عشر عصر النهضة ويقصد بها التحرر من السيطرة الطاغية، سبطرة

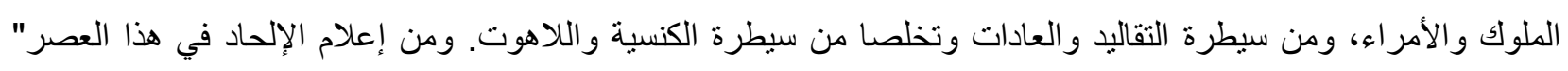

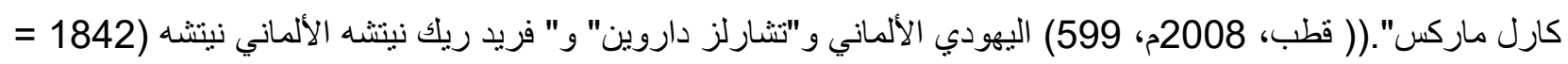
1900 = م) هو: فيلسوف ألماني وفلسفته تزعم بأن الإله قد مات، وأن الانسان الأهل (السوبرمان) ينبغي أن يحل محله.

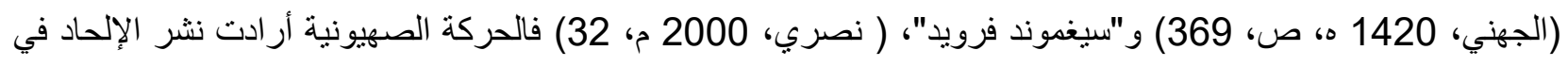
الأرض، فنشرت العلمانية؛ لإفساد الأمم بالإلحاد والمادية، فنشر اليهود نظريات"ماركس" في الاقتصاد والتفسير المادي 
للتاريخ، ونظريات"فرويد"، في علم النفس، هو، سيغمون فرويد (1856 = 1983م) يهودي نمساوي كان طبيبا، و ألف نحو ثلاثين كتبا في الدراسات النفسية، أثهر ها "الذات و الذات السفلي" والمحرمات و تفسير الأحلام. (قطب، 108-109) ونظريات"دارون"،في أصل الأنو اع،دارون هو (شارلس داروين، 1809 = 1882 = م) ولد في بريطانيا و أصدر كتابه في "أصل الأنواع" و هو كتاب مختص في علم الحياة. (البهي، 1982م، 19). وكل هذه النظريات تُعد من أسس الإلحاد في ماني العالم، ويعد هذا من تغلغل اليهودية العالمية عن طريق الماسونية التي تتبني الإلحاد؛ وذللك لهدم مقاومة المجتمع المسيحي

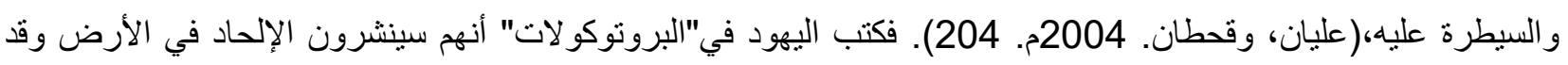

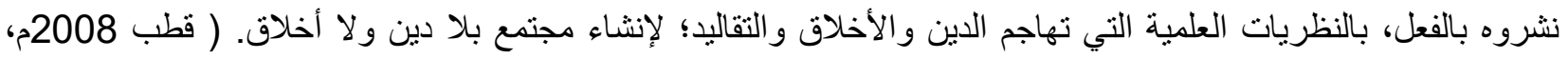

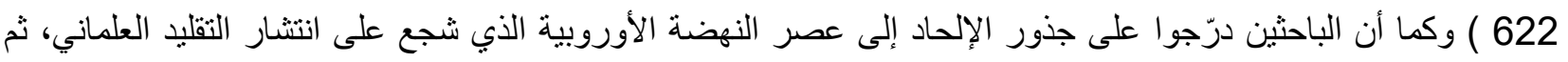
الإلحاد الديني الذي أكد حق الإنسان في التعبير عما يميله عليه ضميره،(عوض، 1997م، 16-20) فعندما حكمت الثيوعية و هي ما كان يعرف بالاتحاد السوفيتي قبل انهياره وتفككه فرضت الإلحاد فرضا على شعوبه، وحاولت نشره في شتى أنحاء العالم عن طريق إخر اجها.

وفي ذلك يقول الباحث البارز" كورس" مؤلف كتاب "الإلحاد في فرنسا ":إن الإحاد لم يظهر إلا في أوائل القرن الثامن

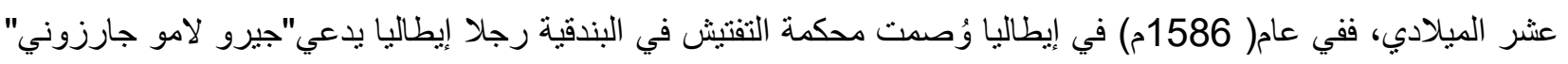

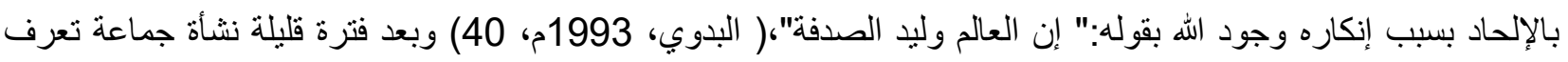
باسم"الأكاديمية المتنكرة" وقد رفعت هذه الجماعة شعار "الإله المجهول" نسبة إلى استبعاد الله من الفكرة، ومن هنا بدأ ظهور الإلحاد في ايطاليا في القرنين الخامس عشر، والسادس عشر، بالأخص و أنحاء العالم بالأعم، ولم يقتصر على الألى الأكادمين و المتعلمين، بل امتد إلى عامة الناس،( طعيمة،2004م،337) و هكذا فإنهم هم الذين أدوا إلى إنشاعة وتطوير الأفكار الإلحادية،

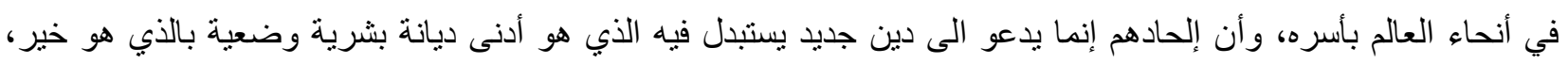
الديانة الإلهية.

\section{ثالثا: نشأة الالحاد في البلاد الاسلامية}

ما ذكرناه من نشأة الإلحاد هو حال الغرب وصر اعها الفكري مع نشر الإلحاد ونشأته من معسكر ومجنمع الغربي ثم الإسلامي،يتبين لنا أن انتشار ات الحركات والأفكار الإلحادية في الوقت الحاضر وكذا القديم بين المسلمين بدأت بعد سقوط

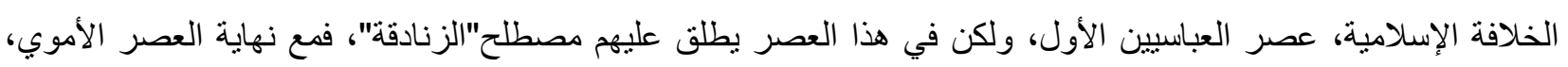
وبداية العصر العباسي، ابتدأت مجتمعات المسلمين تتعرض لموجات من الاحتكالك الأجنبي المعادي للإسلام و لأهله، وكانت

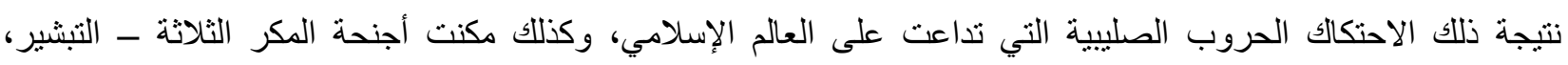

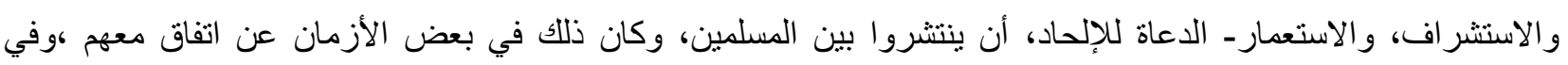

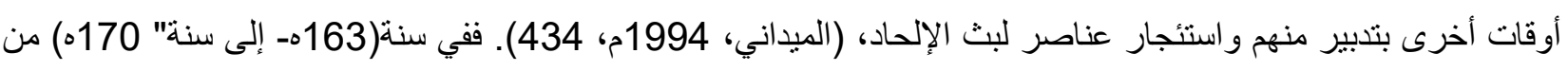
السنوات الأخيرة من خلافة "المهدي"، وأبان خلافة "الهادي" قصيرة الأجل، ظهر نوع من الأفكار الزندقية، فكان "المهدي"

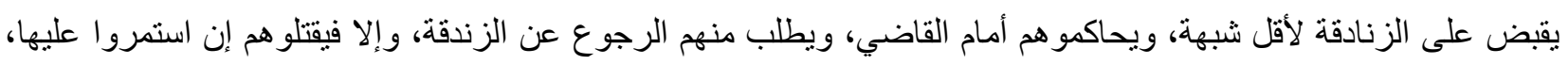

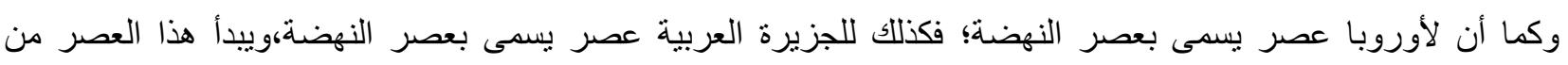

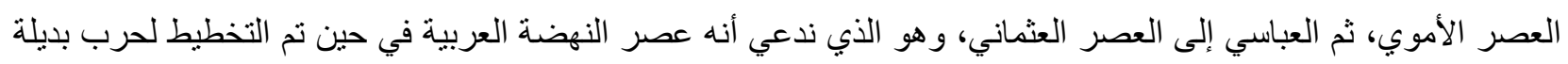


ممثلة في الاستشر اف و التنصير وأخير ا الصهيونية، ومنذ ذلك التاريخ و الإسلام مستهدف من قبل خصومة خارج أرضه وبين أهله. ( البدوي، 1993م، 40-41-

ولعل أول من أظهر الإلحاد في هذه المرة هو"بشار بن برد" (710 - 784م)، أبو معاذ الضرير ويلقب بالمر عث،(الذهبي، 1413، 7 / 24). الذي مات تحت السياط،( نصري، 2000 م، 157). ونسب ونس إليه شيء من الزندقة

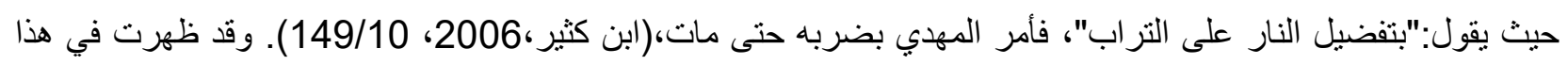
العصر مجموعة كبيرة من الأدباء ومعظمهم لا يدينون بأفكار إلا لما هو مترجم من الفكر الغربي، والقاسم المشترك بين النهضتين - الاروبية والإسلامية- هو التوفيق التلفيقي بين نراثهم و بين ما يريدون استبداله منه بقطع غيار تراثية غربية.

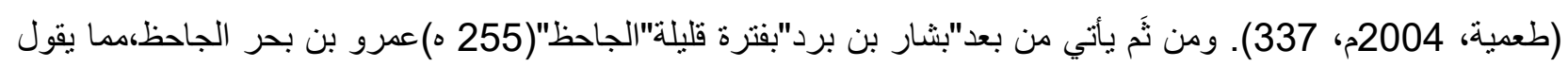

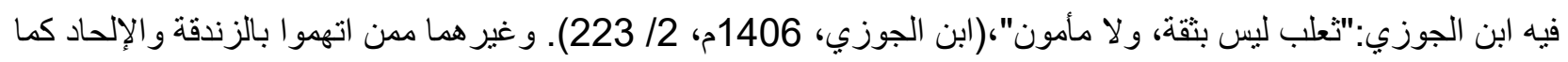

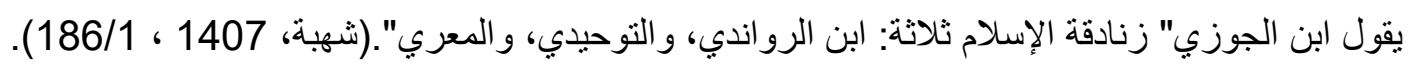
ابن الرواندي،(210 - 300هـ)، وهو أبو الحسن الثيعي، أحمد بن يحيي بن إسحاق، فيلسوف مجاهر بالإلحاد،

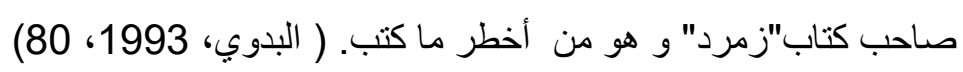
التوحيدي، نوفي(380 ه)، أبو حيان التوحيدي الضال الملحد، وهو على بن محمد بن العباس البغدادي الصوفي،

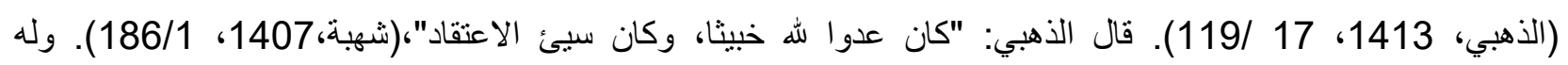
كتاب"المحاضر ات و المناظرات" ونفاه الوزير الملهبي؛ لسوء عقيدته، وكان يتفلسف. (العسقلاني 1413، 1986م، 17 / 38). وكذلك المعري، وهو أحمد بن عبد الله بن سليمان أبو علاء المعري الثاعر، وله شعر يدل على الزندقة. (العسقلاني

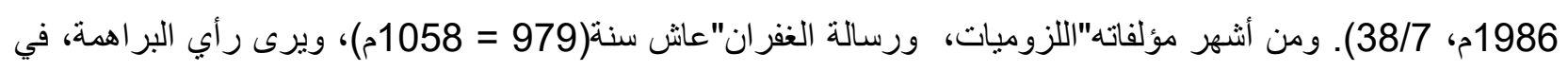

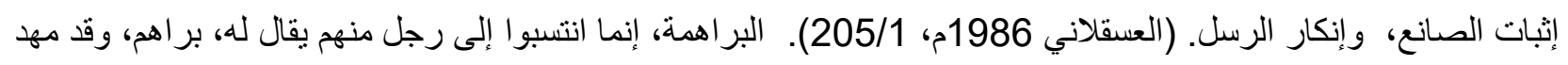

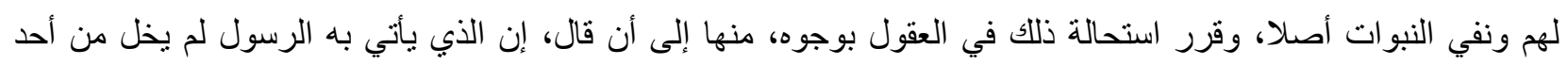

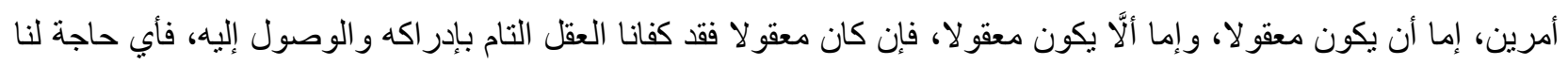

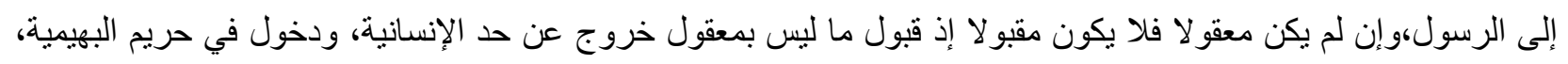
(الثهرستاني، 1404، 249 24).

ومع مرور الزمن، ومنذ بداية تسريب الخصوم من الخارج لأساليبهم وخططهم تشكل الإطار العام لخصوم الدعوة في

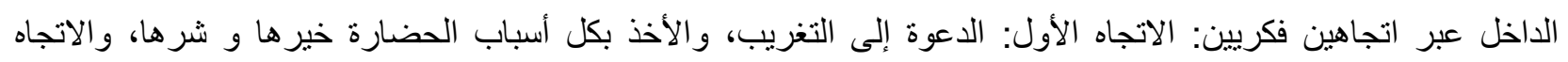

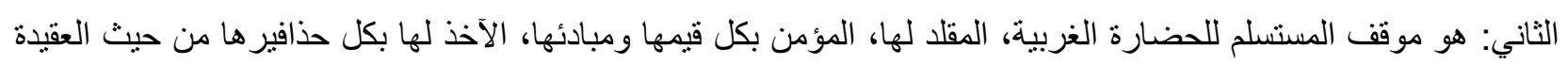
و المناهج الفكرية وغيرها من النظم. (طعمية، 2004م، 337-338). ومن المعلوم أن ميادين الإلحاد الحديثة في الفلسفات

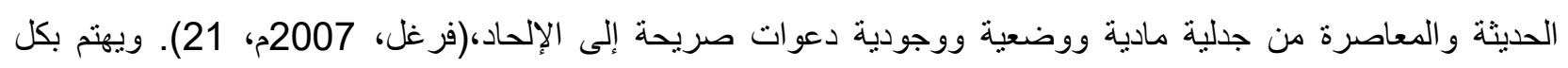
وسائل، وأفكار، و المناهج التعليمية مما يؤثر على المسلمين بتغيير عقيدتهم ومبادئهم الإسلامية السمحة الحنيفة، وبعد فهذه هي الئه نبذة قليلة من تاريخ نشأة الإلحاد وانتشاره في العصرين القديم و الحديث، أو بالأحرى الإسلام و ما قبله.

المطلب الثالث: أنواع الإلحاد واسبابه 
النوع الاول: يتمثل في إنكار وجود الله -تعالى-، والقول بأزلية المادة، و إنها أصل الكون،(طعمية، 2004م، 10). وهو ما يسمى بالإحاد الإنكاري أو الإلحاد الكامل؛ لأنه إلحاد موصل إلى الثرك بالله، وهذا النوع مخرج عن الملة؛ لأنه أوجب الكفر ، و هو ينافي الإيمان ويبطله، ( الأصفهاني، 1426م، 737)؛ (ابن حميد، وابن ملوح،2007م، 9 /3982). وهو إلحاد قوي أو إيجابي بنفي الله، وهذا النوع من الإلحاد نفي و الإلغاء بالتفكير نفي لنفي. ( نصري، 2000 م، 280). فالملحد القوي ينفي وجود الله، وقد يستعين بنظريات علمية أو عقلية فلسفية؛ لإثبات ذللك، فينكار وجود الله، ويقول بمادية الكون لم يعرف

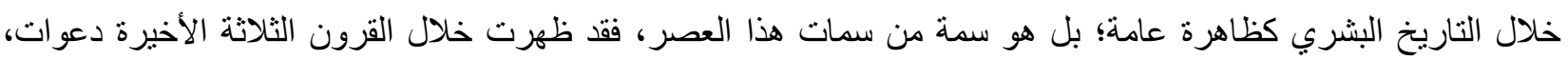
ومذاهب، وفلسفات، تحمل لو اء المجاهرة بإنكار وجود الله - تعالى-، و تقول: بأزلية المادة، وتسند الخلق الذاتي إليها،(طعمية،

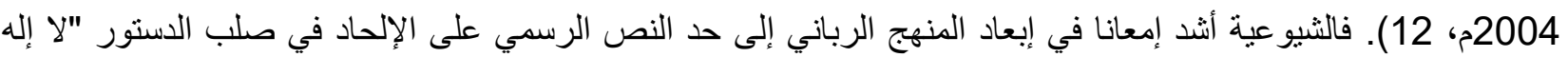

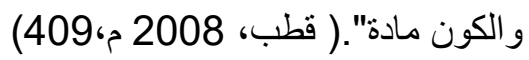

ومما يبدو أن هذا النوع في نفسه معتقد بأن هذا الكون لا بُدَّ له من إله خالق موجود، ولكن بنظرياته المستخدمة،

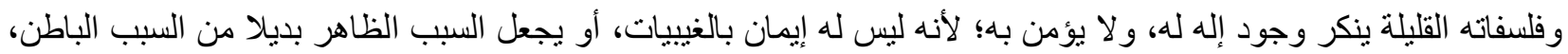

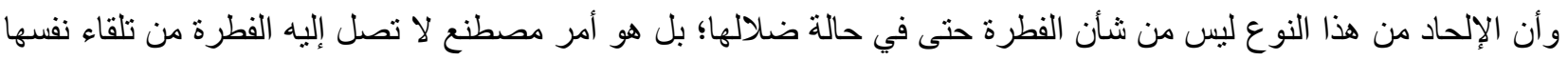

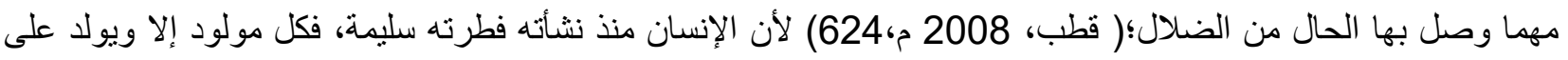
الفطرة، والفطرة تدعو إلى الإيمان بخالق لهذا الكون، و لا يبعدنا عن طريقة معرفة الله -جل جلاله-،كما قالو ا بالقول:"بأن الكون موله

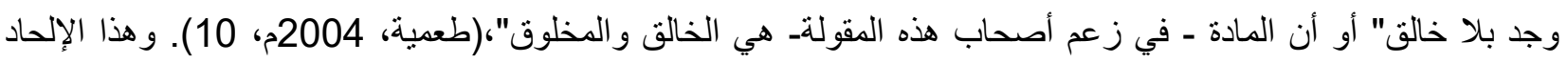

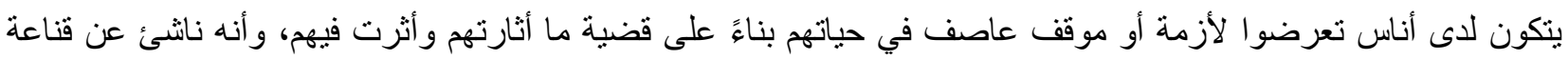

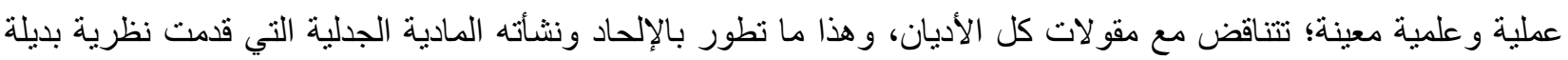
عن الدين في النظام الاجتماعي و المادي، وتطور هذا النوع في أوروبا في عصر النهضة بسبب قمع الهيئات الدينية و غضبها على العلماء، وذلك باستخدام العقل على وجه مفرط، ومن هنا إذا كان الإلحاد يتمرد في زعمه على الأديان بوجه عام، فإن

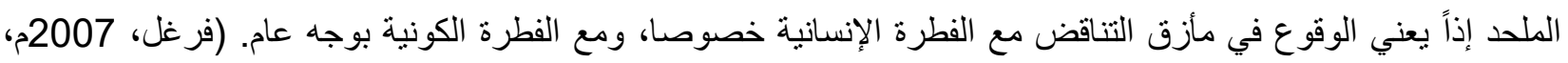

النوع الثاني: إلحاد يكون بالثرك بالأسباب،( الأصفهاني، 1426م، 737)؛ (ابن حميد، وابن ملوح، 2007م، 9

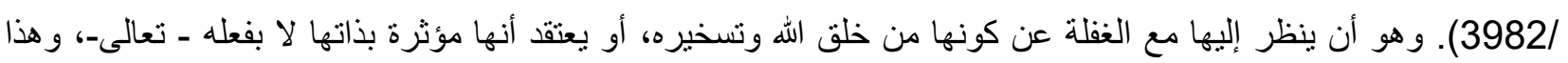

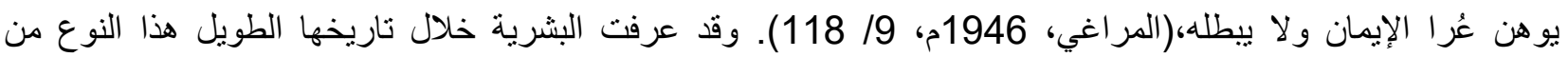
الإلحاد، فرأينا جماعات أنكروا البعث، وطوائف أنكرت الرسالات الإلهية، وجماعات أشركت مع الله آلهة أخرى،(طعمية،

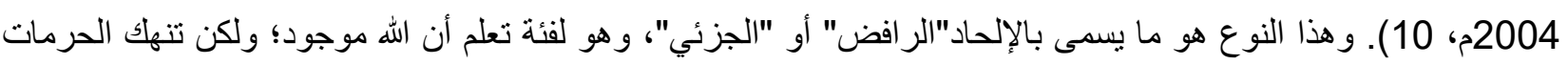
وتسخر من الدين، ويطلق عليه اسم الإلحاد الكاذب، وهو مخرج عن الملة؛ غير أنه في منزلة أقل من سابقتها، وهو بالنسبة للإيمان يوهن عراه ولا يبطله، (الأصفهاني، 1426م، 737). أب لا بلزم من القول به الكفر التام بموجد الكون؛ (طعمية،

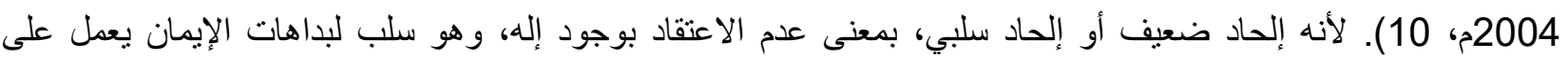


ترسيخ بداهاته لا بصحنها بحد ذاتها؛( نصري، 2000 م، 188). لأنه يتمثل في اتخاذ شركاء مع الله - تعالى-، أو تكذيب بالرسالات الإلهية، و إنكار البعث وما فيه من حساب ونعيم و عذاب،(طعمية، 2004م، 10). و يدخل ضمن هذا النوع الإلحاد في "آيات الله"، والإلحاد في "الحرم"، وكذا الإلحاد في "أسمائه -تعالى-"؛ لأن الإلحاد في "آيات الله" هو الميل عن الحق في في

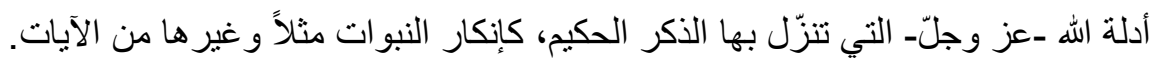

\section{ثانيا: أسباب الإلحاد}

يرى البحث أن هنالك أسباب كثيرة ومتفرقة يتوصل بها الملحدون إلى إنكارهم لوجود الله ونفيه وجحود آياته، وهو ما

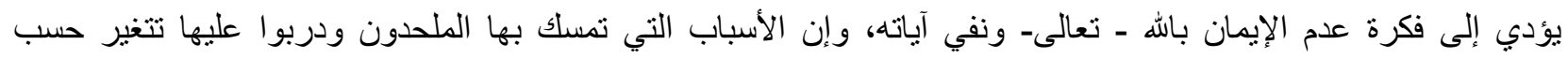
عصور هم و أفكار هم في العصرين ـالقديم و الحديث- أو الإسلام و وما قبله.

الإلحاد في كل زمان ومكان طريق للإباحية والتخلي عن المثل العالية؛ لذا كان الإلحاد ملاذاً لأصحاب الثهوات و المنحرفين عن الخلق الرفيع، (عليان، وقحطان. 2004م. 113). وقد ذكر الباحثون كثيرا من الأسباب المؤدية إلى إلحاد الملحدين، وميلهم عن الطريق المستقيم و المنهج الرباني القويم، ونذكر أهم الأسباب لهذه الفكرة التى تَجُرُ الملحدين إلى الإلحاد. أولاً: الإعراض عن علوم الاين، وعدم التعرف عليه، و إلا من عرف ما جاءت به الكتب السماوية، أو بالأحرى ما جاء به دين الإسلام، ولو معرفة متوسطة يستحيل أن يقع منه الإلحاد جهلا أو ضلالا؛ (السعدي، تنشأ عن قناعة علمية معينة، تتناقض مع مقو لات أي دين من الأديان،كما يقول البدوي: "فريق تزندق فر ارا من تكاليف الدين؛ وطلبا لسلوك مسلك الحياة الماجنة الحرة السمحة، دون أن يتأثر بشك فكري واضح، كما هى الحال بالنسبة إلى كثير من

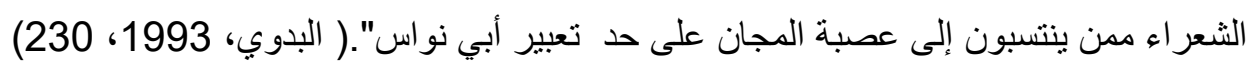
ثانياً: الغفلة، التي تعترى بعض الناس، فتعطل عقولهم وقلوبهم؛ فيغفلون عما حولهم من آيات الله المبثوثة في الكون،

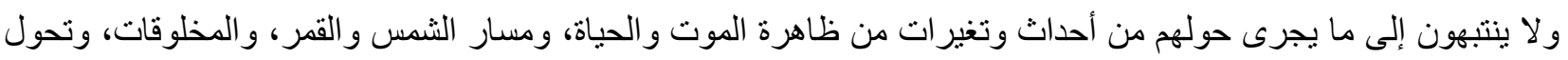
الكائنات، (طعمية، 2004م، 10). وقد وصفهم الله - تعالى- في القرآن الكريم بأنهم أهون شأن من البهائم وأضل عنهم سبيلا

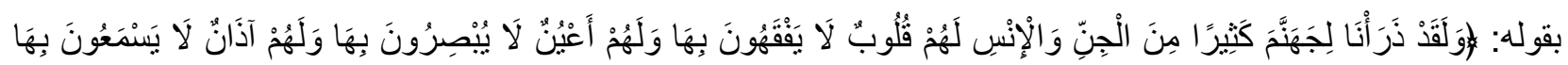

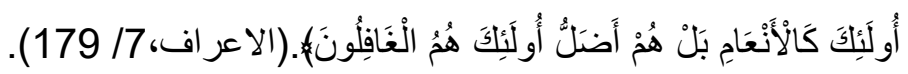

ثالثثاً: حب الثهوات، وهذا من أثند أسباب لجوء الكثيرين إلى الإلحاد، وهو حب الثهوات والرغبة الجامحة في الافلات،(سندي، 2013م، 25). فيلحد شخص لسبب مادي نفعي، بأن ينكر وجود الإله في سبيل مصلحة مادية يرى أنها تتحقق له بذلك، و أنه طريق لحلها بالإلحاد، فلا حلال و لا حر ام في ظلال مملكة الإلحاد. رابعاً: الإعلام، فيتملق الثخص لفكرة الإلحاد بسبب متابعته للإعلام الفاسد السلبي المتمسك بفكرة الثر والثشيطان و اتباعه، كما هى حال المعسكر أو المجتمع الشرقي، حيث يفرض الإلحاد فرضا في مناهج التعليم ووسائل الإعلام،( قطب، لإبل 2008،) وهي معركة تستخدم فيها جميع الأسلحة وجميع الوسائل بلا حساب، و التي تجند لها القوي و الكفايات وأجهزة الإعلام

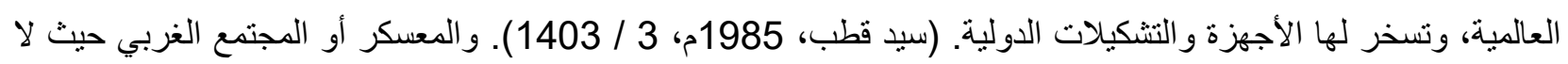
يفرض الإلحاد على الناس بتلك الصورة؛ ولكن يشجع الناس عليه بكل وسائل التشجيع(قطب، 2008م، 624). وهذا ما تمسك 
به وصلار عليه بعض الملاحدة في العالم الإسلامي ومجتمعات المسلمين، بنشر أفكار الإلحاد والتشجيع عليها، و السبر على مناهج الغربية.

\section{المطلب الرابع: أضرار الإلحاد وآثاره على المجتمع}

فكرة الإلحاد بفلسفته واستخدام العقل العملي أو الإفر اط فيه ينشأ مجتمعا فوضويا و أفكار ا عشو ائية، لا يدرى أين ينوجه؟ و إلى أين يتجه؟ لأن الإحاد بكل صوره الخاصة والعامة، يغيب عن الإنسان الحقيقة الرئيسة فى كل ما يتعرض له الإنسان فى له له لهان

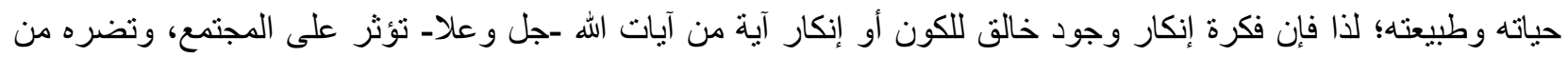

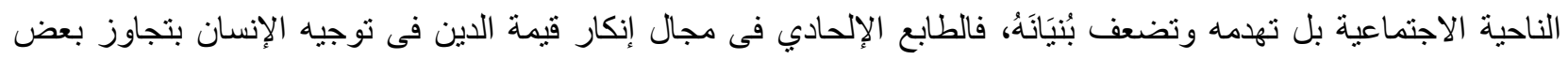

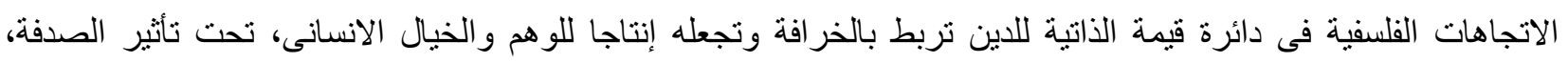

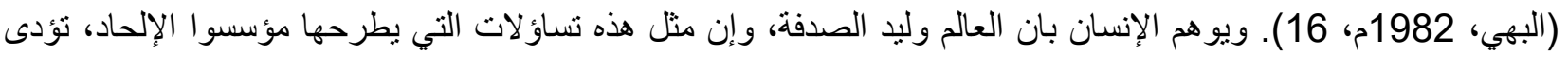
فى نهاية الأمر الى تثكيك الإنسان فى الدين، (عوض، 1997م، 24). و هذا ما يهدف إليه الإلحاد؛ بان ذهنية الإلغاء التي تحكم الوعظ، هى نفس ذهنية الإلغاء التي تتمرد عليه بالإلحاد باستخدام العقل استخداما قصير النَفَس؛( نصري، 2000 م، 280). لأن الإلحاد بالذات هدف أساسي من أهداف المخطط الثرير من قبل اليهود الذين نشروه، فهدفه الأخير من المخطط كله، هو إزالة كل دين فى الأرض؛ لييقى اليهود وحدهم فى الأرض أصحاب الدين.( ( قطب، 2008، 622-623) ) و إن تغلغل اليهودية العالمية، تتبنى الإلحاد؛ لهدم مقاومة المجتمع المسيحي و السيطرة عليه. (عليان، وقحطان، 2008م، 113).

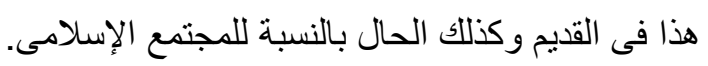

الإلحاد حرمان من البحث عن المطلقات، يؤدى إلى حجز العقل بالفكر، وبالتالى عدم السماح له بالوعي. (نصري،

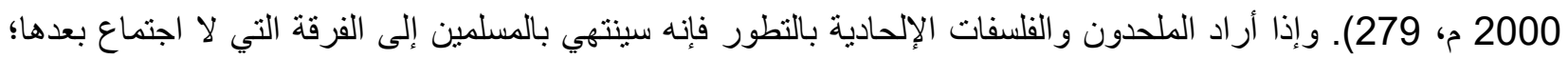
لأن كل جماعة منهم سوف تذهب فى التطوير مذهبا يخالف غيرها من الجماعات، ومع تو الي الأيام نجد ثقافة إسلامية، عربية، وتركية، وكردية، و هندية، و إيرانية، و هكذا حتى تصبح الأمة الإسلامية أنثلاء ممزقة. (طعمية، 2004م، 333). المؤسسات التعليمة الإلحادية فى مناهجها مهما قويت لا تزيد الناس سوى الابتعاد عن مشكلة أساسية وهى مشكلة معنى وهدف ومصير الوجود الإنسانى، التي لا نريدها العلوم و الفلسفات الإلحادية إلا يأسا وعبثا و غيابا فى المعنى. (نصري، 2000 م، 156). ومن الواضح أنه متى قطعت الصلة بين الإنسان وبين الغاية المثلى من وجوده فى هذه الحياة، أمسى ماديا أنانيا دنيويا صرفا، والمادية التي لا تخشى الله نر افقها باستمرار بواعث الجريمة لتلبي مطالب النفس وأهو ائها و شهواتها. (الميداني،

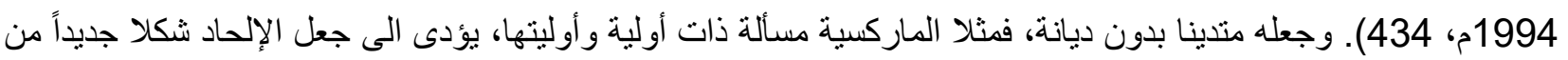
الدين، ولقد وقعت بعض الحملات ضد الدين من طرف مجموعات شيو عية. (الصعيب، 2009م، 33). فهكذا بريدون إفساد الإسلام وأهله، وذللك بتشويه قيمه ومفاهمه الأصلية بإدخال المزيف على الصحيح، وإثبات الغريب وغير ذلك. (طعمية،

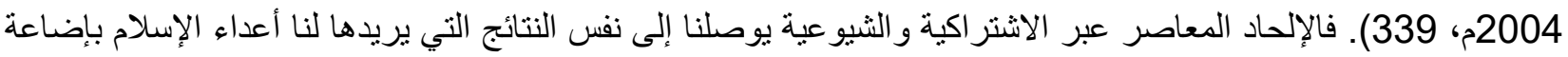
هويتنا، وبالتالى إضاعة كل فرصة لنا بأي أمل. نصري، 2000م، 281). وأن الملحدين قد قتلوا بين جوانحهم بإلحادهم مقتضيات الفطرة والبداهة والحس، و أنه لم تكن لديهم حجة يتذرعون بها، أو سند يستندون اليه. (طعمية، 2004م، 11، 11). ففكرة الإلحاد يريد إفساد الثعوب الإسلامية خاصة فى عقائدها وأخلاقها و آدابها وسائر أنواع سلوكها فى الحياة. (الميداني،

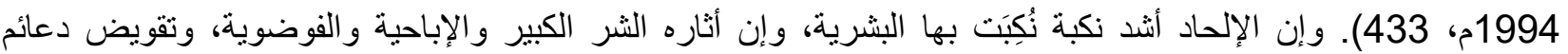


العمران، والسير إلى الهلاك و الثقاء، (السعدي، 2003م، 70). و الفساد والتعصب والقومية والثُعوبية، التي تحركت منذ بداية العصر العباسي، هى الثعوبية نفسها التي تحركت ضد الإسلام، وهى التي تتحرك اليوم بالإلحاد المعاصر عمالة

$$
\begin{aligned}
& \text { لإسر ائيل وللقوي التي تقف ور اءها. ( نصري، } 2000 \text { م، 280-281). } \\
& \text { فيتضح لنا أن أضرار الإلحاد الأساسية للإنسان ما يلى: } \\
& \text { أولا: الإلحاد، ينافي الإيمان ويبطله ويؤدى إلى سوء العاقبة في الدنيا والآخرة. } \\
& \text { ثنانيا: الإلحاد طريق مؤدٍ الى غضب الله ورسوله؛ لانه تملص للإباحية. } \\
& \text { ثالثا: هدد الله الملحدين بأنه سيعاقبهر بالنكال و الخسران. }
\end{aligned}
$$

رابعا: الإحاد يربي مجتمعا فوضويا وأفر ادا عنصريين شريريين هو ائيين، ويكون سبباً لهدم النظام الأسري، وللقلق و الصراع النفسي، والأنانية والفردية، وكذا فقد الوازع الديني، والنزوع إلى الإجرام، ويحويل المجمعات إلى فئات غارق في وحل الجنس و الفاحشة و الفجور، كما يحاول تغيير طبيعة الدين.

$$
\text { المبحث الثاني: الإلحاد في القرآن الكريم }
$$

إن القرآن الكريم حذرنا من الإلحاد، و نبّهنا من التجنب مما يفعله الملحدون، ومن صفاتهم الذي يقومون به، وذلك بنصوص صريحة، وغير صريحة، حيث صرّح في بعض الآيات إلى لفظ الإلحاد، وأشار في البعض الآخر إلى ما يفهم منه

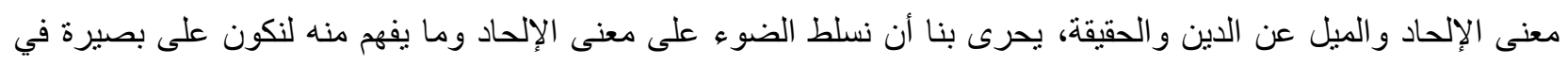
موضوع الإلحاد ومصطلح هذه الكلمة حسب ما ورد في النصوص القر آنية، وفهم العلماء و المفسرين لهذا المعنى.

\section{المطلب الاول: الالحاد ومرادفاته في القران الكريم}

$$
\text { أولا: الالحاد في القران الكريم }
$$

$$
\text { وردت في القرآن الكريم أربعة نصوص تذم الإلحاد نوردها موجزة فيما يأني: }
$$

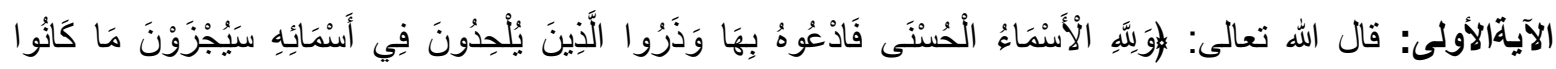

$$
\text { يَعْمَلُونَ). (الاعر اف، 180/7). }
$$

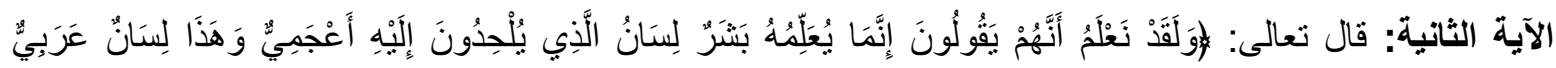

$$
\text { مُبِينُْج).(النحل، 103/ 103). }
$$

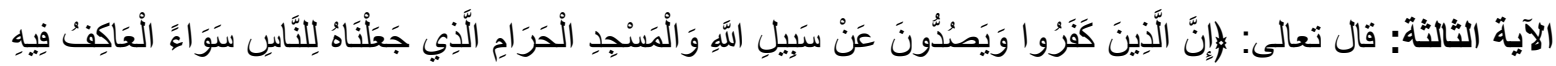

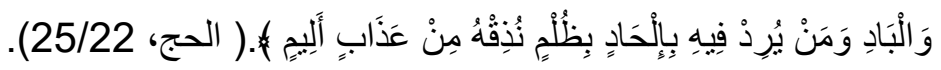

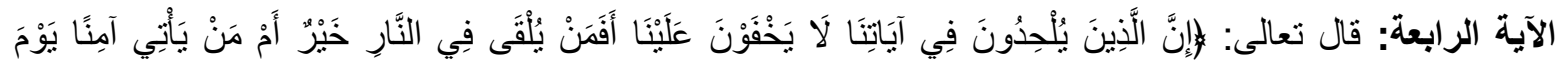

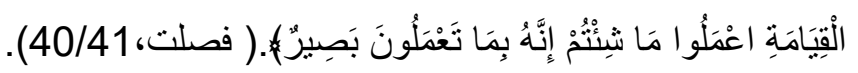

$$
\text { ثانيا: مرادفات كلمة الإلحاد }
$$


فالإلحاد له مر ادفات كثيرة وكلمات عديدة من مسمى واحد مشابهة لمعناه أو متقاربة منه في الاستعمال اللغوي مثل

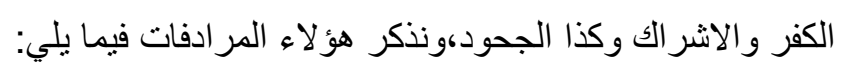

1 الكُفْر: 1

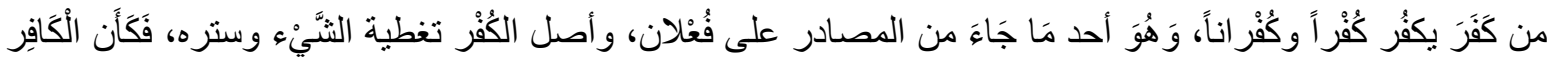

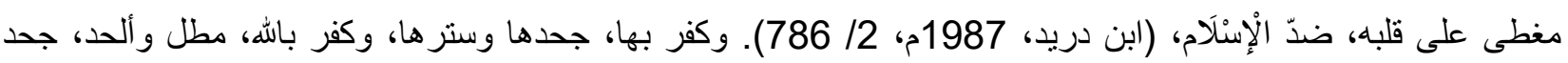

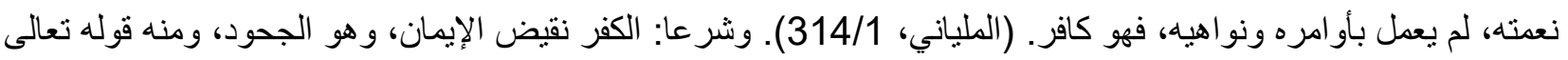

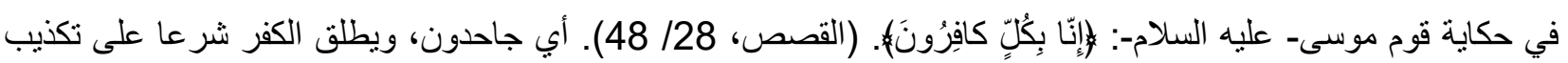
النبي محمد -عملوسلمه -في شيء مما جاء باه من الدين ضرورة. (عبد المنعم، 1/ 487).

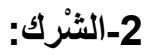

الثنين و الر اء و الكاف أصلانِ، أحذُهما يدلُّ على مقارنَة وخِلاَفِه انفراد، و الآخر يدلُ على امتدادٍ واستقامة، فالأول

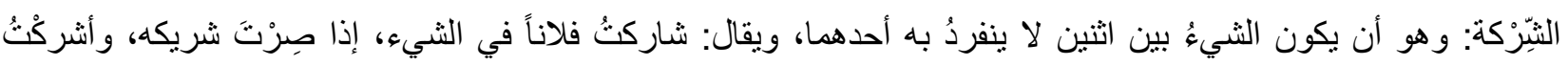

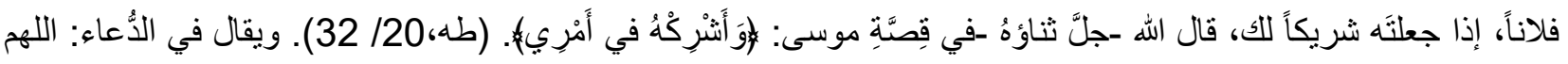

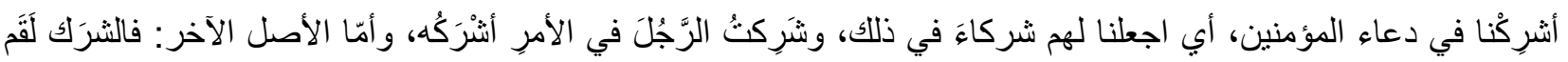

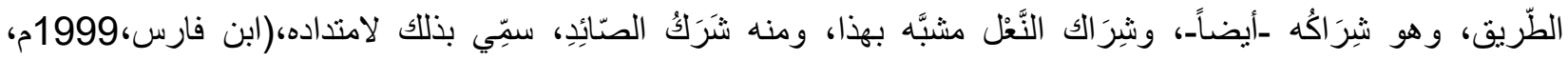

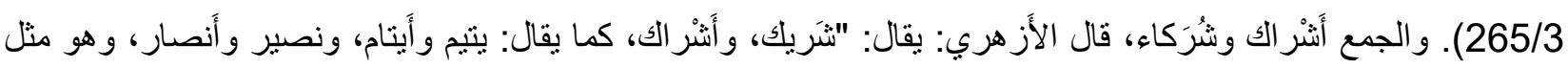

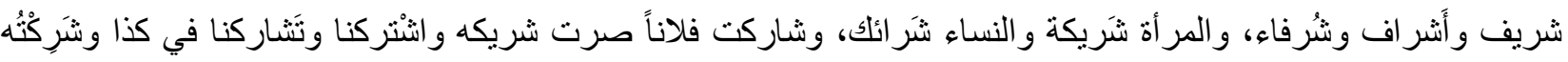

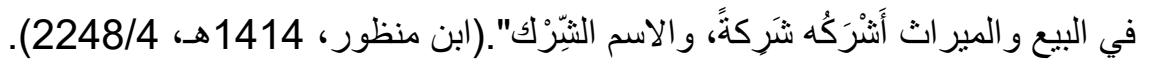

3-الجُحُود:

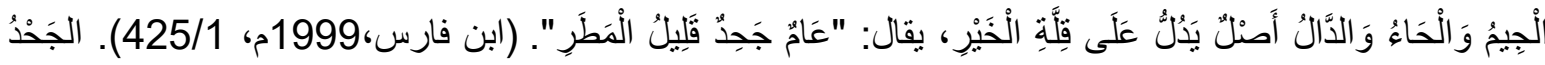

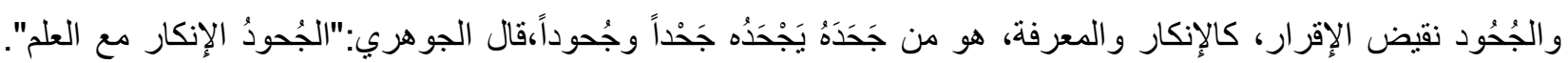
(ابن منظور، 1414 هـ، 537/1).

اذاً فالجحود هو ، إنكار ما سبق له وجود، وهو خلاف النفي إذ هو إنكار نفس وجود المدعي.( المناوي،1990م، 1921 ) وقال الراغب:"الجحود نفي ما في القلب إثباته أو إثبات ما في القب نفيه". ( الأصفهاني، 1426م، 171/1). و والجحد يقال فيما ينكر باللسان لا بالقلب.

\section{المطلب الثاني: أسباب الالحاد وأنواعه في القران الكريم وقد حدد القرآن الكريم أسباب الإلحاد بما يلى:}

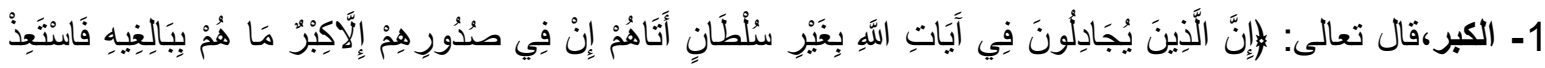

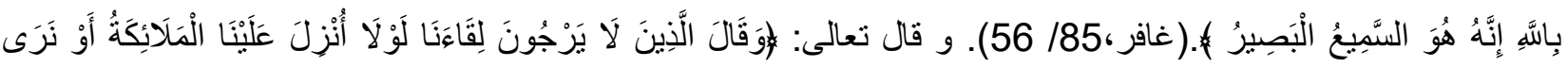
232 


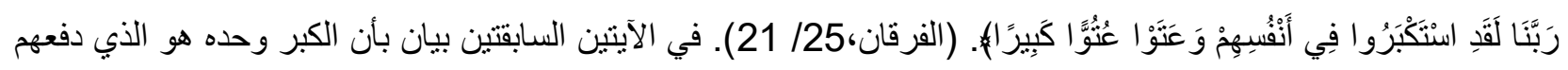
إلى تصور الحياة هى كل شيى، وليس وراءها إلا العدم،(عليان، و قحطان ، 2004م،، 108- 109). أب "و الله لقد استكبروا

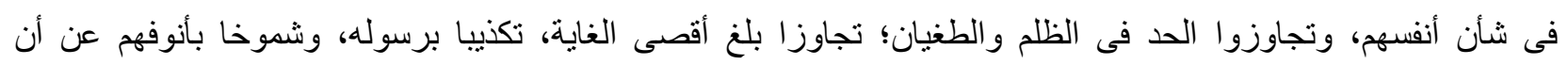

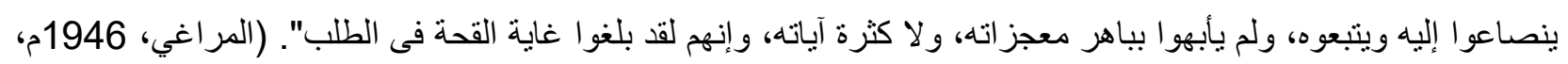

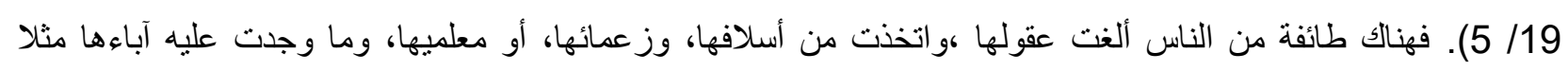

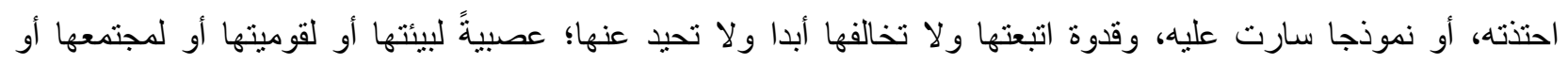
لقبيلتها،(طعمية، 2004م، 12). وفريق تتاز عه عاملين فجمع بين "سلوك المجان" و بين"عصبية الثعوبيين" و إن هذه الحركة المتصاعدة الفكرية تبلغ أوجها عند "ابن الرو اندي"، فصارت مذهبا شاملا أقيم عليه أسس من العقل، وأصبح ذا أنسان أنصار يؤمنون

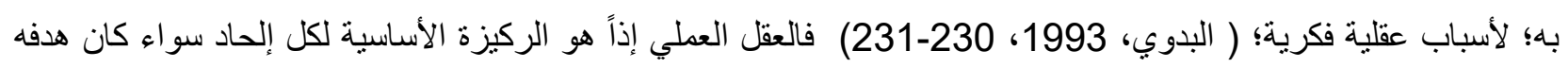
الثعوبية قديما أو العمالة حديثا، وهذا العقل العملي، هو الذي سموه بالعقل بصورة مطلقة. ( نصري،

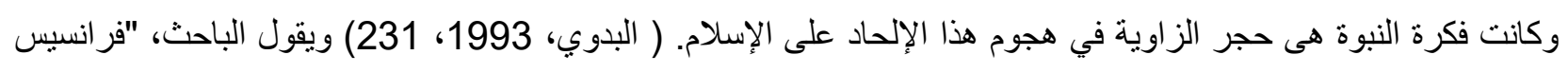
بيكون"(1561-1626م)،إن قليلا من الفلسفة يقرب الإنسان من الإلحاد، أما التعمق في الفلسفة فيرده إلى الدين. (عليان، وقحطان، 2004م، 105). و هذا ما يصير عليه الملاحدة الآن باستخدامهم الفلسفة القليلة، و لا يتعقون فيها، فيخوضون في في الإني الإلحاد الصريح بكبر هم.

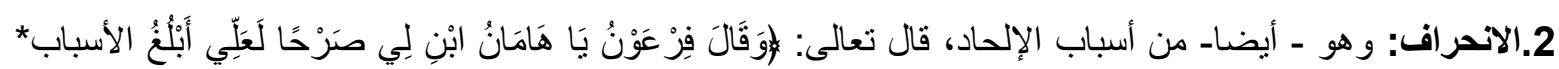

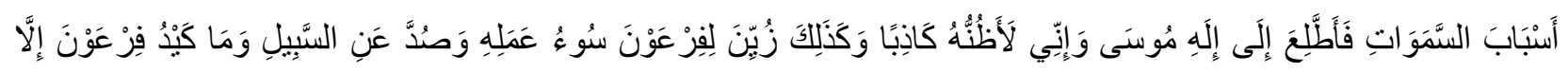

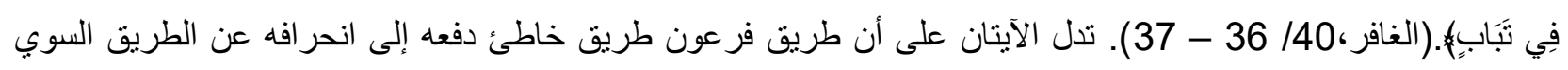
الذي يعرف به الله - سبحانه وتعالى-(عليان، وقحطان، 2004م، 109). إن تكبر فرعون وجبرونه قد وصل به إلى عنوّه

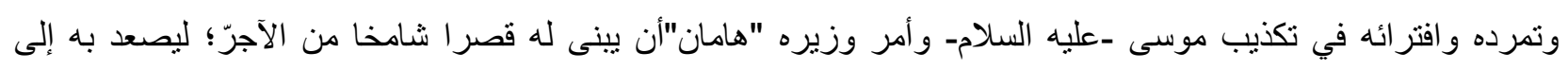

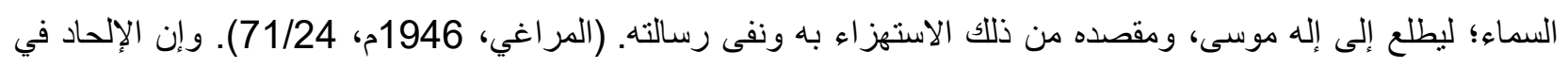

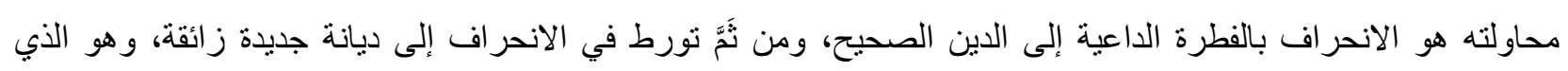

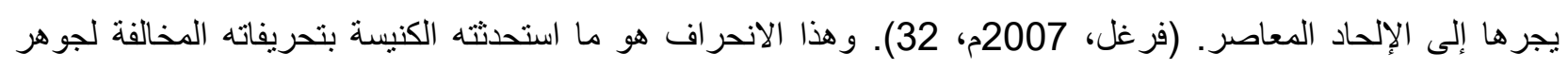

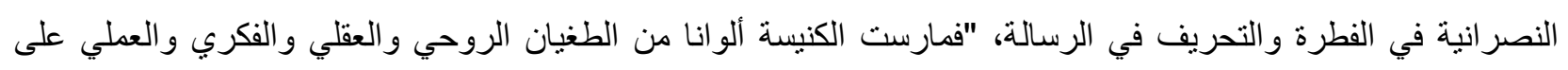

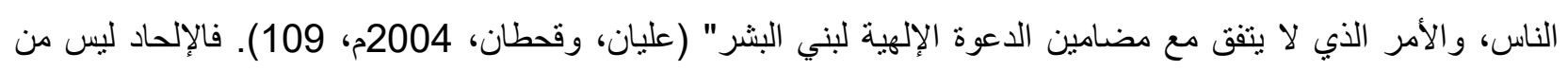

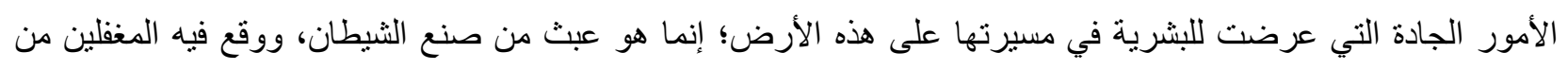

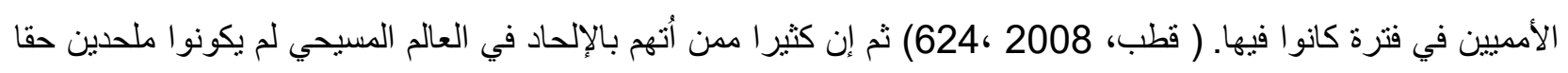

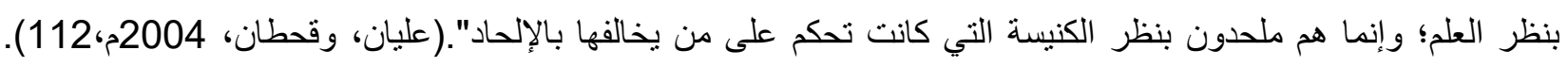

و أخير ا فإن الانحر اف يعد من استحداث أمور ومبادئ الكنسية المسمي بالهرطقة ويؤدي إلى الإلحاد عن المبادئ الدينية.

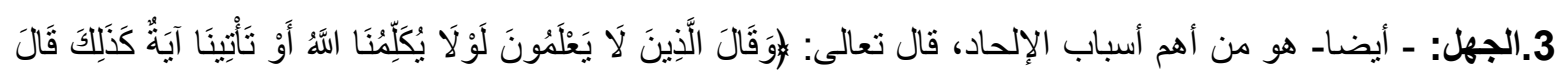

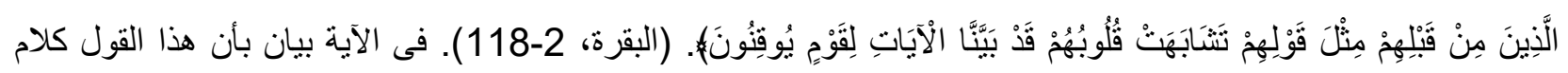

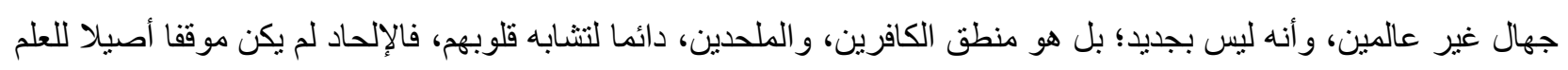
بل هو من الجهل، و انما أحدثته ظروف خاصة، (عليان، وقحطان ، 2004م، 109-113). فقوله: "لا يعلمون"،أي الجاهلون 


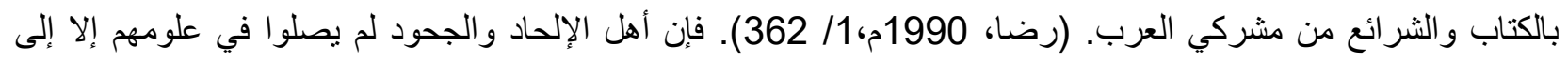
جهل مركب أو جهل بسيط أو جحود مع العناد. (السعدي، 2003م، 66). فبو اعن اعث الإلحاد، أنها شعور بالجهل إزاء المشاكل

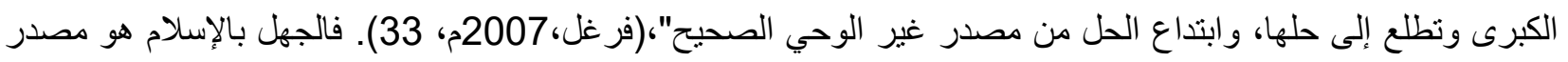
كل عداوة، فأكثر الناس جهلا بالإسلام أثدهم عداوة له، وهو الفرصة الوحيدة؛ لانتقاص منه والهجوم عليه. (البوطي، 2007م، 99). فالمنهج العلمي فهو منطلق الإيمان بالله-عز وجل- ومعرفته،كما قيل: "إذا فكرت تفكيرا عميقا؛ فإن العلوم سوف تضطرك إلى الاعتقاد الكامل بوجود الله - جل جلاله-". (عليان، وقحطان، 2008م، 113). ومن الإنمان المعلوم أن الجهل هو

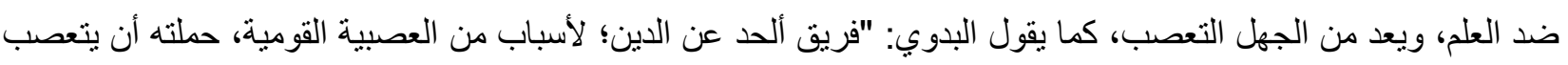
لدين آبائه من المجوس و التنوية المانوية، كما فعل ابن المققع وبشار". ( البدوي، 1993، 230) وتعد العصبية نوعا من الكبر و العناد، وقال شيخ الإسلام ابن تيمية:"وكل من يقبل قول هؤلاء الملحدين فهو أحد رجلين: إما جاهل بحقيقة أمرهم، وإما ظالم

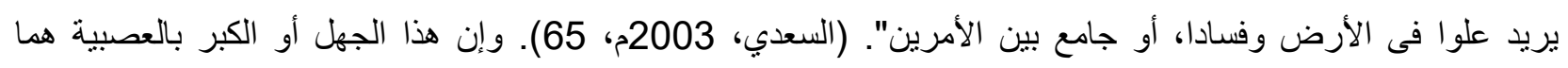
نفسهما اللتان أدنا إلى الإلحاد فى أساس هذه الحضارة التي هى الإسلام. ( البدوي، 1993، 230 ) وفيَّ فجوجا لتندل

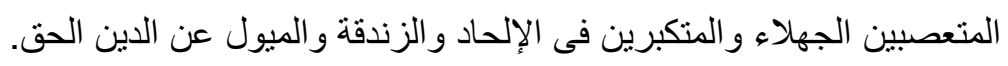

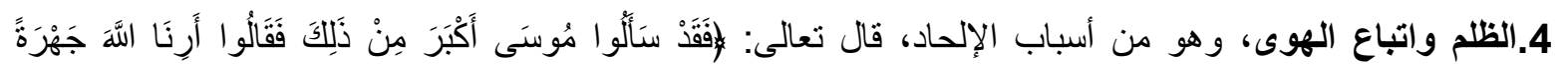

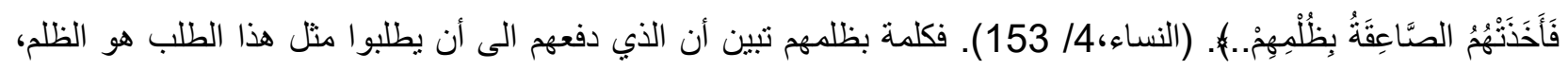

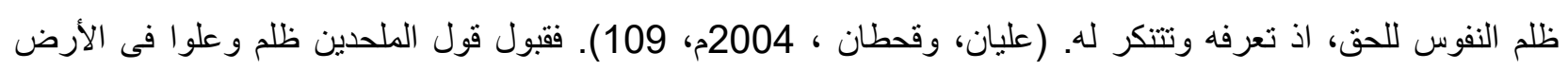

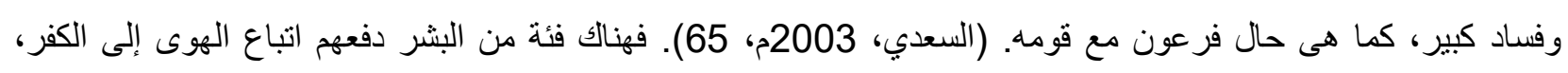

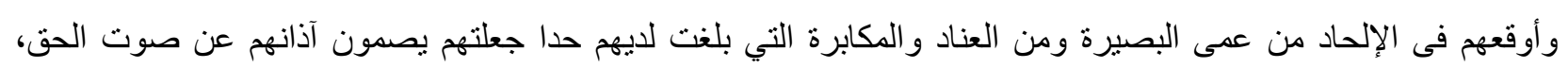
ويغمضون أعينهم عن نور الإيمان. (طعمية، 2004م، 13). فيظلمون أنفسهم ولا يهندون إلى معرفة الحقيقة، وينكرون الحق ونق

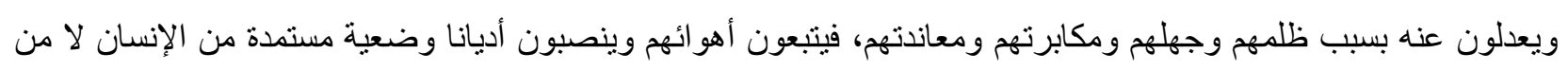

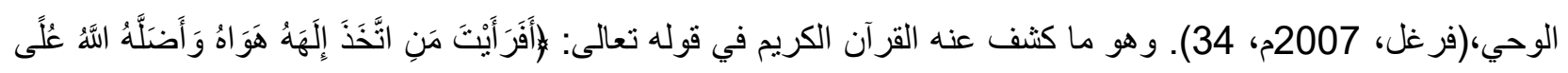

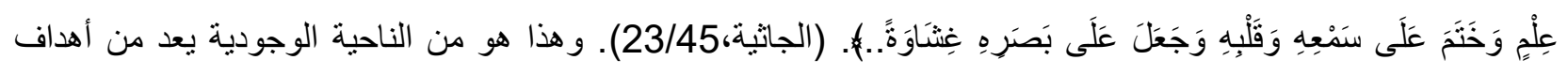
الإلحاد، "أي انظر واعجب من حال من ركب رأسه، وترك الهدى، وأطاع الهوى، فكأنه جعله إلها يعبده من دون الله، فهو لا لأل

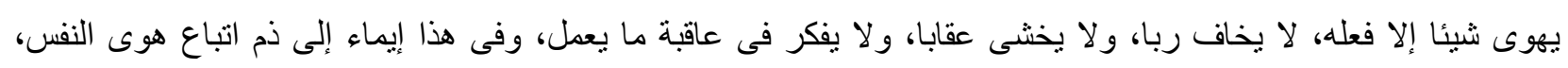

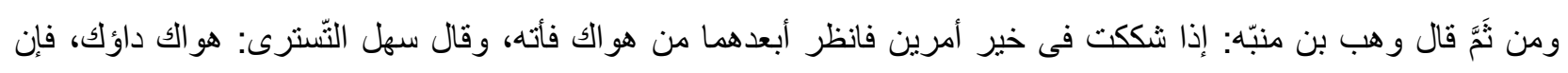

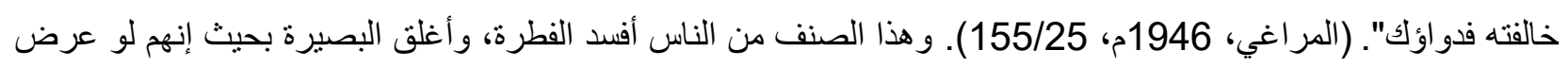

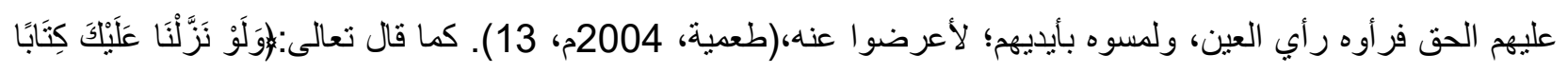

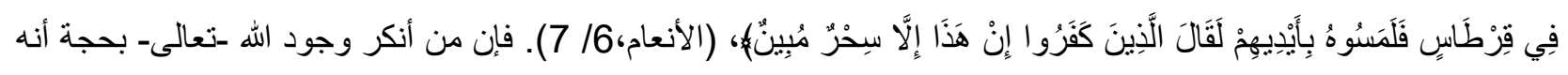

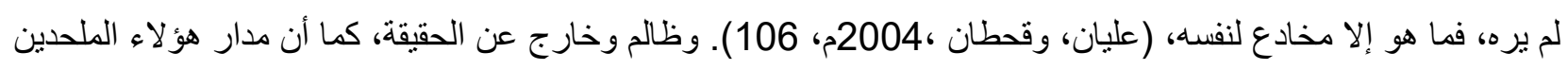

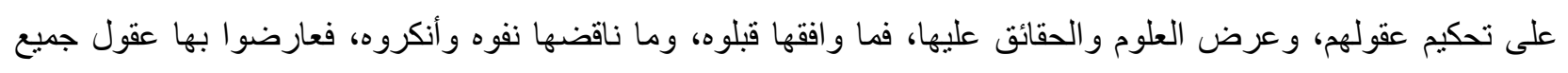
العقلاء و علوم الأنبياء واتباعهم. (السعدي، 2003م، 73). فيضلون ويضلون، و ولا يهتدون إلى حقيقة الإيمان، وييقون على وفئ جكلهم و عنادهم و كبر هم و ظلمهم. 
المطلب الثاني: أنواع الالحاد

أولاً: الإلحاد في آيات الله

الإلحاد ورد في سور القر آن الكريم مختلفة، حيث يذكر بعض المرآت الإلحاد في آيات الله -تعالى- ـ الإلحاد في الحرم، وكذا الإلحاد في أسمائه -تعالى- ومن المعلوم يجب علينا الرجوع إلى ذكر سبب نزول الآية، ومن ثم الإتيان بآر اء المفسرين؛ لنصل إلى معنى الإلحاد و المر اد منه.

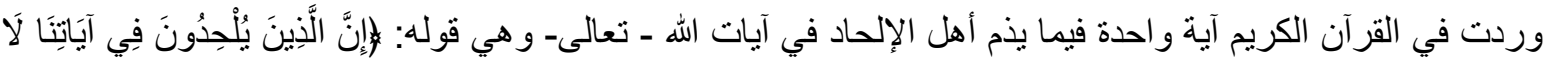

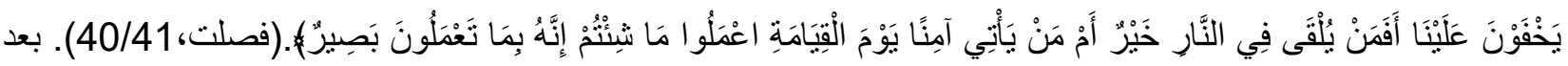

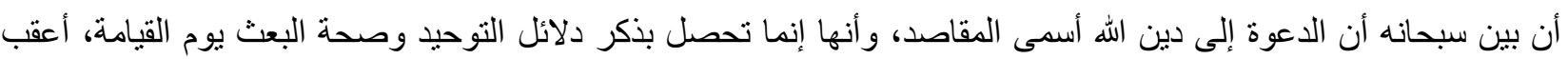

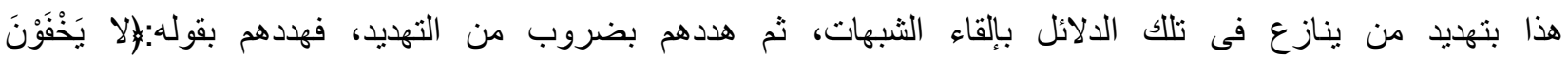

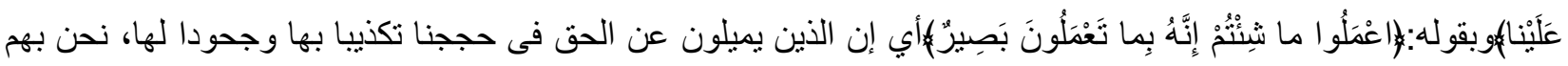
عالمون لا يخفون علينا، ونحن لهم بالمرصاد إذا وردوا علينا، وسنجازيهم بما يستحقون، و لا يخفى ما في ذلك من شديد الوعيد كما يقول الملك المهيب، إن الذين ينازعوننى فى ملكى أعرفهم ولا شك، فهو يريد تهديدهم وإلقاء الرعب في قلوبهم". (المر اغي، 1946م، 137-136/24).

و اختلف المفسرون في المر اد من معنى الإلحاد في هذه الآية على خمسة أقوال:

أحدها: أنه وضع الكلام على غير مواضعه، رواه العوفي عن ابن عباس. (ابن كثير، 2006م، 171/19) ؛ (وابن

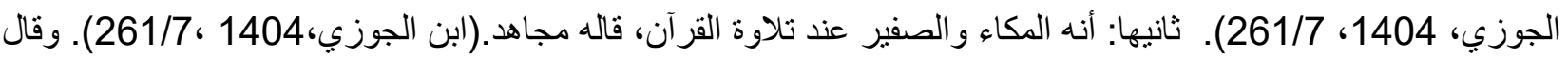

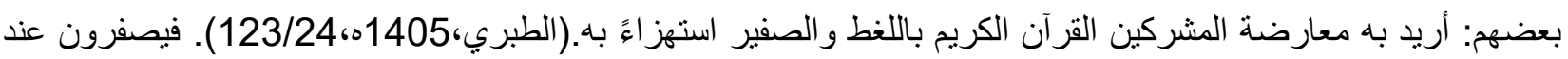
قر اءته. (الآلوسى،126/24). ثالثها:أنه التكذيب بالآيات، قاله قتادة. (الثوكاني، 581/4،و ابن الجوزي، 1404 ، 261/7). أب

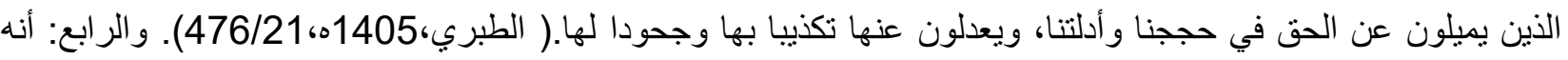
المعاندة، قاله سدي. (ابن الجوزي،261/7). أي يعاندون ويشاقون. (القرطب،

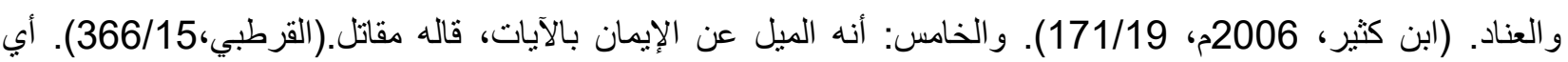

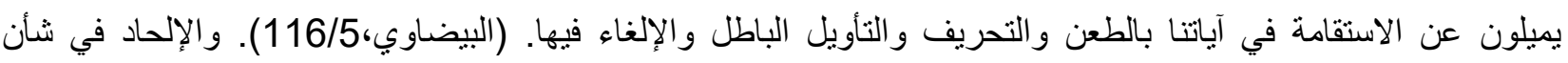
الآيات الطعن في دلالتها والإعراض عنها. (الآلوسي،126/24). وقال آخرون، أريد به الخبر عن تبديلهم معاني كتاب الله،

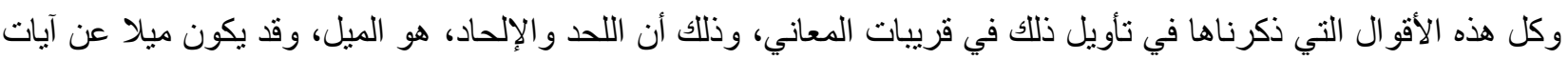
الله، وعدولا عنها بالتكذيب بها، ويكون بالاستهزاء مكاء وتصدية، ويكون مفارقة لها وعنادا، ويكون تحريفا لها وتغييرا لمعانيها، ولا قول أولى بالصحة في ذلك مما قلنا، وأن يعم الخبر عنهم؛ بأنهم ألحدوا في آيات الله، كما عمّ ذلك ربنا تبارك ونك

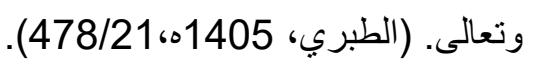

اذاً فالإلحاد في آيات الله، الميل بها عن الصواب، بأي وجه كان، إما بإنكار ها وجحودها، وتكذيب من جاء بها، وإما

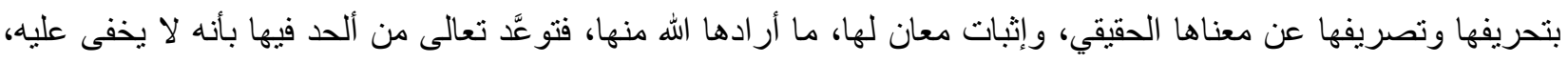

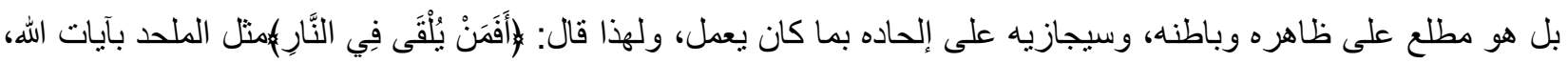




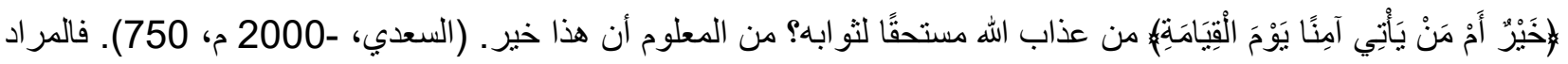

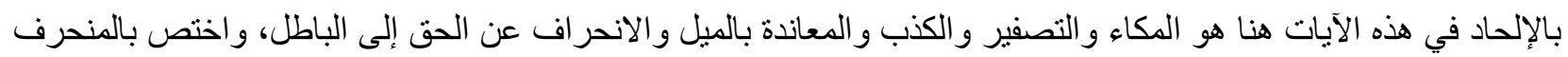
عن آيات الله - جل جلالهـ وبالذين يميلون عن الحقائق الثابتة.

$$
\text { ثانيا: الإلحاد في الحرم }
$$

الباري - سبحانه وتعالى- يذكر في القرآن الكريم أهل الكفر و الإلحاد في حرم الله تعالىـ مكة المكرمة ـ و الذين ينتهكون

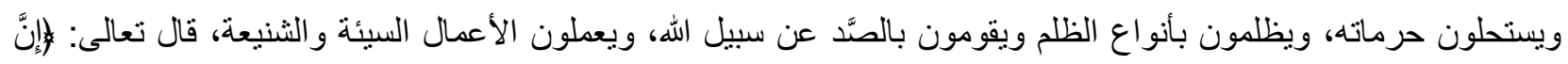

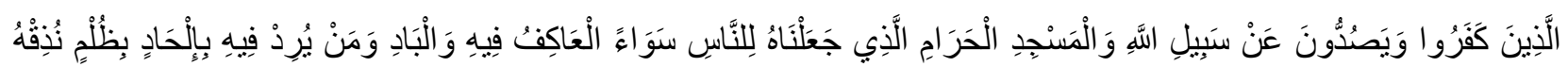

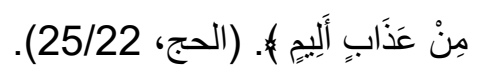

سبب نزول الآية، أخرج ابن أبي حاتم عن ابن عباس قال: بعث البني- علملوسلله - بن أنيس مع رجلين أحدهما: مهاجر،

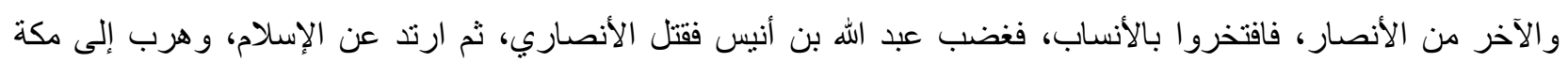

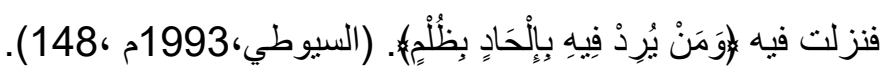

في المراد بالإلحاد في هذه الآية خمسة أقوال: أحدها: أنه الظلم، قاله ابن عباس. (ابن الجوزي،1404ه ، (421/5).و

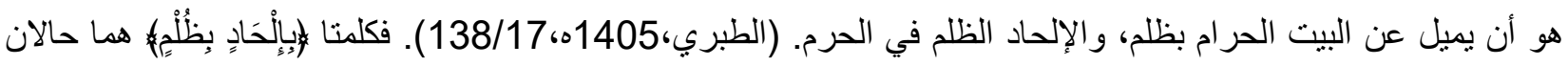

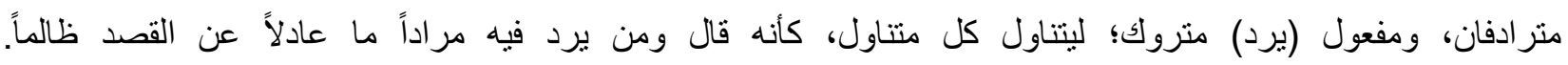

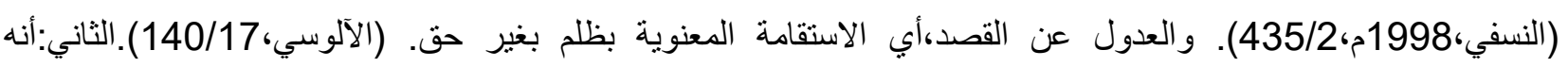
الثرك، رواه على بن أبي طلحة عن ابن عباس. (ابن الجوزي،1404هـ-421/5-422). وقال وقال الحسن وقتادة عن مجاهد: هو "أن يعبد فيه غير الله"(الطبري،1405ه ،140/7). الثالث: الشرك و القتل، قاله عطاء. (ابن الجوزي،1404هـ ، 1421/5-

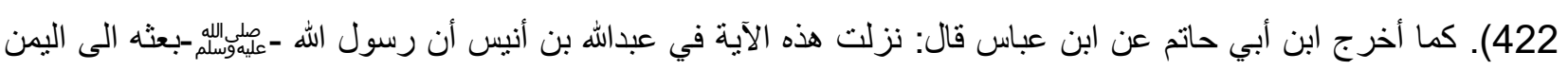
مع رجلين أحدهما مهاجر و الأخر أنصاري فافتخروا في الأنساب فغضب عبد الله فقتل الأنصاري. (الثوكاني،449/3-

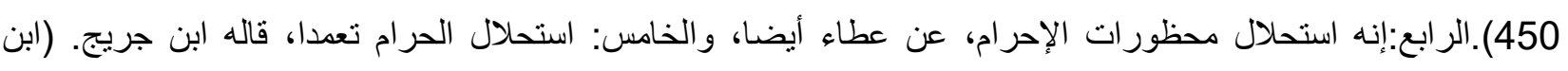
الجوزي،1404ه ،421/5-422). وعن ابن عباس: بعني أن تستحل من الحرام ما حرم الله عليك من لسان أو قتل فتظلم من لا يظلمك و تقتل من لا يقتلك. (الطبري،1405ه،140/7).وقال مجاهد: هو "عمل سيئة"، و عن عمر بن الخطاب انه قال:"لا

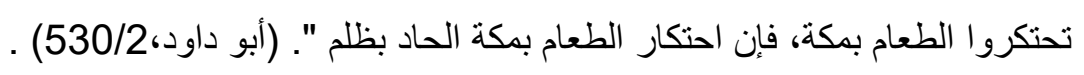

وقال أهل اللغة: قوله:( بظلٍٍ) الباء زائدة، وقال الزجاج: مذهبنا أن الباء ليست بز ائدة، و المعنى، ومن أراد فيه بأن يلحد بظلم، ومعنى الإلحاد فى اللغة"العدول عن القصد" و أما المبتغى فى الإسلام سنة الجاهلية، فهو طلبهم بالذحول غير القاتل،

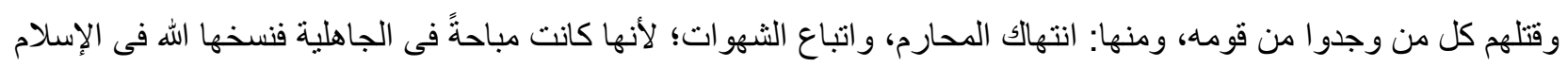

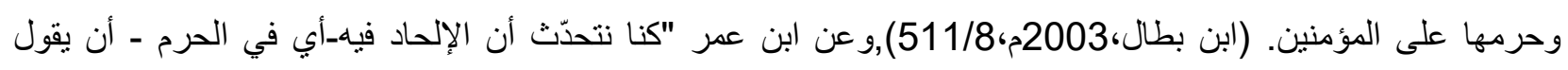

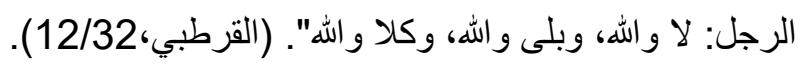


إذا فالمر اد بالإلحاد في هذه الآية، هو أن يميل و يحيد عن دين الله الذي شر عه ويعم ذلك كل ميل وحَيدة عن الدين كفعل

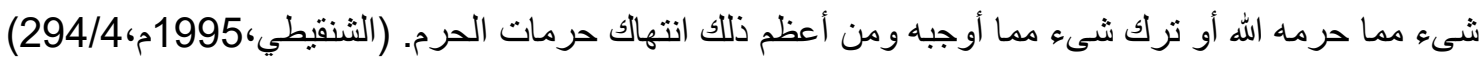

\section{ثالثا: الإلحاد في أسمائه تعالى}

الإلحاد بكل أقسامه و أنواعه فيه تهديد وو عيد من الله- تعالى-، لمن يعتنق ويركن إلى هذا الفكر الخبيث الذي يكون سببا لكثير من المشاكل الاجتماعية وجميع الأمور الحياتية مما يتعلق بتطور جوانب حياتنا اليومية الخاصة، فالقرآن الكريم له نهجه الخاص وأسلوبه الفائق في البلاغة حينما يشير إلى مثل هذه الأفكار المصنوعة من قبل بني البشر، ومن ضمن هذه الأقسام

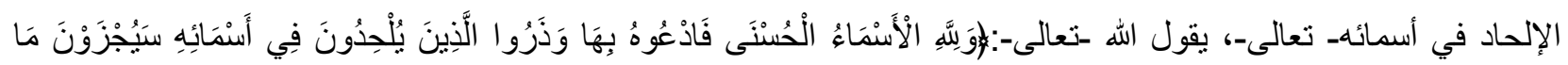

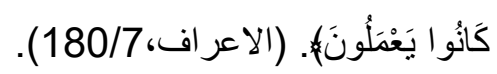

سبب نزول الآية: ذكر مقاتل و غيره من المفسرين أن هذه الآية نزلت في رجل من المسلمين، كان يقول في صلاته: يا رحمن يا رحيم، فقال رجل من المشركين: أليس يزعم محمد وأصحابه أنهم يعبدون ربا واحدا؟ فما بال هذا يدعو ربين اثثين؟

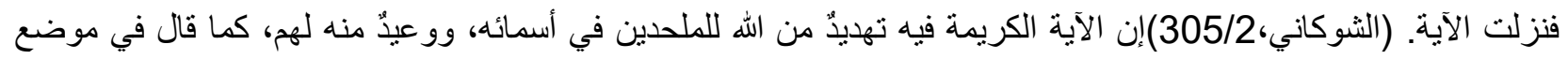

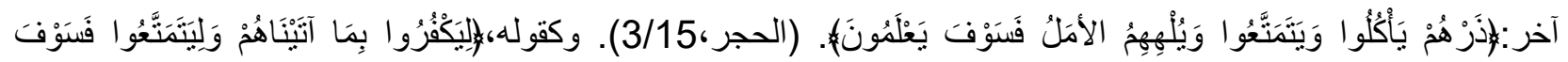

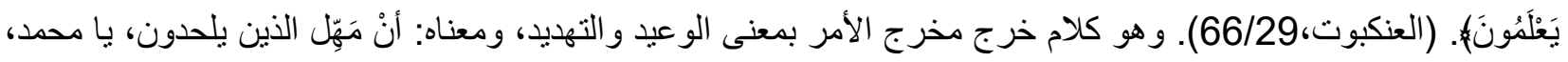

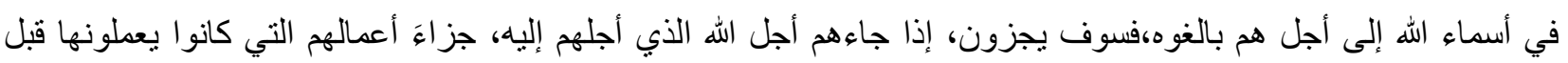

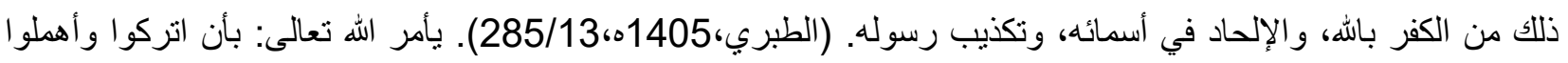
بلا مبالاة جميع الذين يلحدون في أسمائه بالميل بألفاظها أو معانيها عن منهج الحق الوسط، إلى بنيات الطريق ومتفرق السبل،

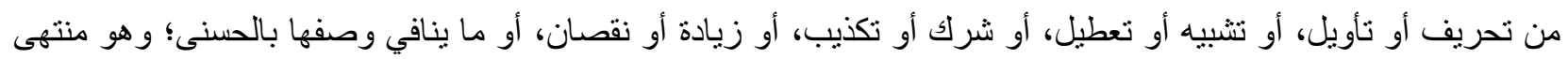
الكمال، ذروا هؤلاء الملحدين، ولا تبالوا بهم، وكأن قائلا يقول: ولماذا نذرهم في خوضهم بعمهون؟ فأجاب بقوله

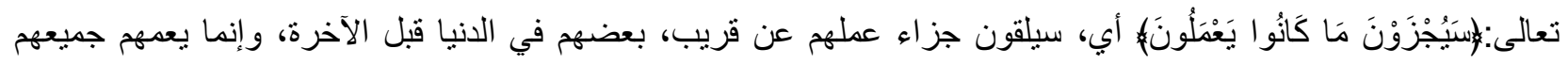
عقاب الآخرة، إلا من تاب منهم قبل الموت. (رشيد رضا، منا، 1990م ، 368/9).

للمفسرين و أهل التأويل أقو ال كثيرة في معنى"يلحدون" في هذه الآية، قال العوفي عن ابن عباس قال: إلحاد الملحدين أن دعوا اللات في أسماء الله،(ابن كثير، 2006م، 107/19). و عنه -أيضا-: أن إلحادهم في أسمائه؛أنهم سمّوا بها أوثانهم، وزادو ا فيها و نقصو ا منها؛ فاتنقوا اللات من الله، والعزى من العزيز، ومناة من المنّان. (ابن الجوزي،293/3). وقال ابن جريج عن مجاهد نفس قول ابن عباس،(ابن كثير، 2006م، 171/19). وقال بعضهم: يكذبون، وقال آخرون: يشركون، (الطبري،134،9).و أخرج ابن أبي حاتم عن الأعمش أنه قر أ "يَلَحدون" من اللحد، وقال تفسير ها: "يدخلون فيها ما ليس منها"، (السيوطي،1993م،617/3). وذللك أن يسموه بما لا يجوز عليه، نحو أن يقولو ا: يا سخي،يا رفيق؛ لأنه لم يسمى نفسه بذلتك.

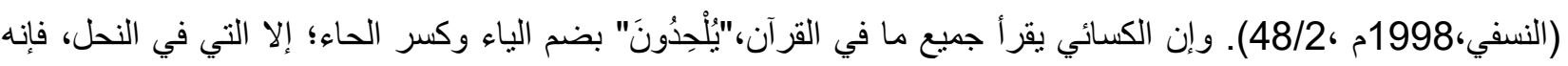

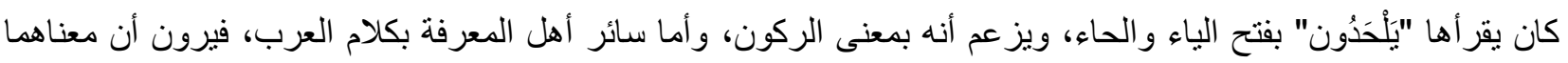

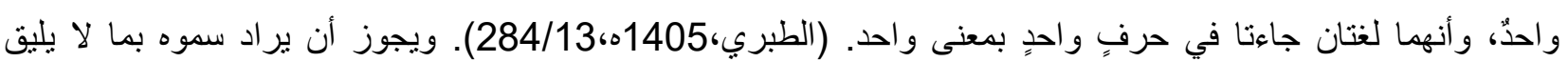

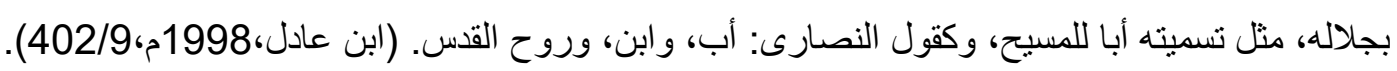


و اتفق أهل الحق على أن أسماءه وصفاته تعالى توقيفية، ونصو ا على إثبات كل ما ورد في الكتاب و الأحاديث الصحيحة دعاء ووصفا له، و إخبارا عنه، و على منع كل ما دل على منعها، ومنه كل ما يسمى إلحادا في أسمائه، وكل ما أوهم نقصا أو

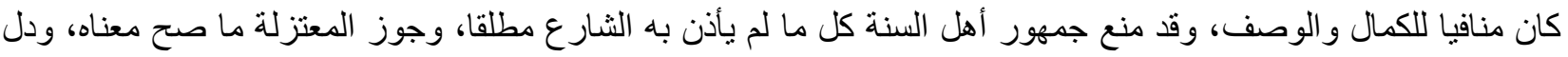
الدليل على اتصافه به، ولم يوهم إطلاقه نقصا، و الفلاسفة أوسع حرية في هذا الإطلاق، وقد عدوا عليه من إساءة الأدب قوله لخالقه،وقد ذكر ذلك السفاريني في شرح عقيدته "الخلاف بين أهل السنة والمعتزلة" ثم قال: ومال إليه ـأي قول المعتزلة بالجواز - بعض الأشاعرة كالقاضي أبي بكر الباقلاني، ونوقف إمام الحرمين الجويني، وفصل الغزالي فجوز إطلاق الصفة، و هي ما دل على معنى زائد على الذات، ومنع إطلاق الاسم، وهو ما دل على نفس الذات، واحتج للقول المعتمد "أنها توقيفية"؛ بأنه لا يجوز أن يسمى النبي -عليهوسلمه - بما لبس من أسمائه فالباري أولى، وتعلق المعتزلة بأن أهل كل لغة يسمونه سبحانه باسم مختص بلغتهم كقولهم: "خداب"، وشاع من غير نكير، ورد بأنه لو ثبت لكان كافيا في الأذان الثرعي، ونقل الآلوسي في تفسيره سياق السفاريني إلى احتجاج المعتزلة بعدم إنكار أحد من المسلمين على إطلاق الفرس "خدا"، وز اد عليه اسم "تكرى" وهو نركي، وكافه نون في النطق، وقال: إنهم ادعوا أن هذا إجماع، وأنه لو ثبت لكان كافيا في الأذان الشرعي. (رشيد إشيد

رضا،1990م 1971/9).

و على هذا فالإلحاد في أسمائه - تعالى- يكون بثلاثة أوجا: إحدها: بالتغيير فيها كما فعله المشركون، وذلك إنهم عدلوا بها عما هو عليه فسموا بها أوثانهم. (القرطبي،328/7).وتسمية الأصنام آلهة، وهذا أعظم الإلحاد في الأسماء.

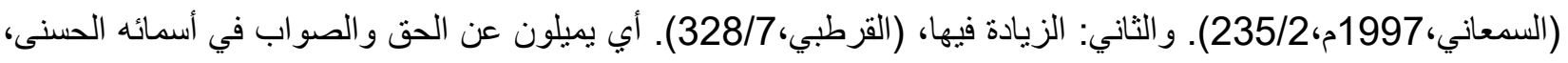

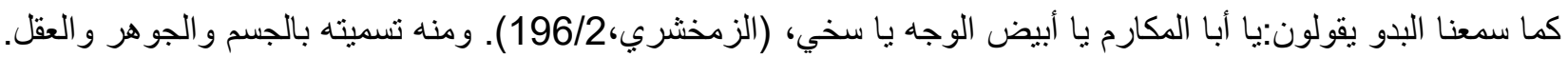
(النسفي،1998م ،48/2).والثالث: بالنقصان فيها، كما يفعله الجهال الذين يخترعون أدعية يسمون الله تعالى بغير أسمائه، (القرطبي،328/7). و وعن عطاء-فيالآيةالإلحاد في أسمائهـ قال:الإلحاد المضاهاة. (السيوطي،1993م ،617/3). وقال الخطابي: ودليل هذه الآية أن الغلط في أسمائه و الزيغ عنها إلحاد. (ابن الجوزي، 1404ه ،293/3). و على هذا فإن الإلحاد فى أسمائه الحسنى يكون بتسميته -تعالى- بما لم يسمّ به نفسه فى كتابه، أو ما صح من حديث رسوله عليؤسلم. (المر اغي، 1946م، 19/ 118-119). أو ترك تسميته بما سمى به نفسه أو وصفها به، أو ترك إسناد ما أسنده تعالى- إلى نفسه من الأفعال بناء على أن ذلك لا يليق به -تعالى-6، أو أنه يوهم نقصا فى حقه، كأن هؤلاء الملحدين أعلم منه ومن رسوله- عليؤسلهم- بما يليق به وما لا يليق،وتغيير أسمائه بوضعها لغيره مما عبد من دونه كاللات والعزّى، وكذا تحريف أسمائه وصفاتهـ تعالى- عما وضعت له بضرب من التأويل، فقد ذهب جماعة من المسلمين إلى جعل رب القدوس الذي ليس كمثله شىء، كرجل من خلقه؛ لأنه -تعال-ى وصف نفسه بصفات يدل مجمو عها على ذلل، كالسمع و البصر ، والكلام، والوجه، و اليد، و الرجل، و الضحك، و الرضا، و الغضب، وذهب آخرون إلى تأويل جميع صفاته -تعالى- حتى جعلو ها كالعدم، و إنر الك غيره فيما هو خاص به من أسمائه باللفظ كاسم الجلالة "الله" و الرحمن، ورب العالمين، وما فى معناه كرب السماء والأرض،

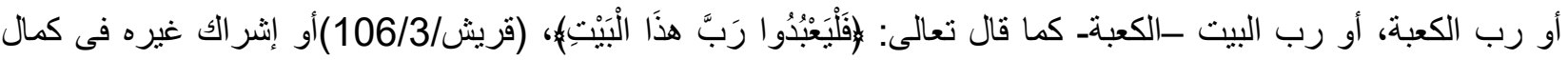
أسمائه؛ كمن بزعم أو يعتقد أن لغيره رحمة كرحمنه، ورأفة كر أفته وغير ذلك من معانى أسمائه كالمجيب مثنلا كما فال

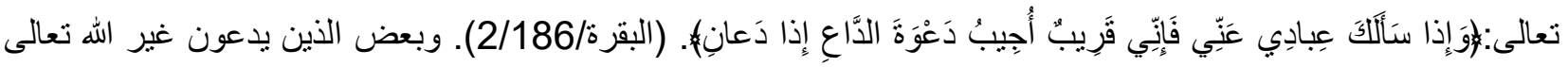
من الموتى يعتقدون أنهم أسرع و أقرب فى إجابتهم من الله تعالى فيجمعون بذللك بين شركين، شرك دعاء غير الله، مع اعتقاد 


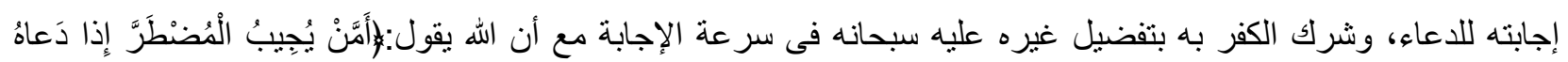

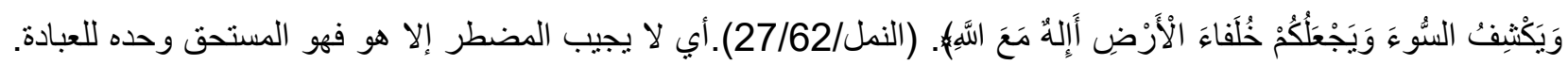
دون غيره. (المر اغي، 1946م، وده و19 119-120). 
الخاتمة

الحمد اله وحده، و الصلاة و السلام على من لا نبي بعده، سيدنا وحبيينا محمد صلى الله عليه وآله وصحبه ومن سار على نهجه ودربه إلى يوم الدين. ففي ختام البحث أوجز الكلام فيما توصلت إليه من نتائج ما بلي: 1- إن الصر اع الفكري الإلحادي بما ذكرنا من تعريفاته ونشأته و أسبابه و أنو اعه و أضراره، هى غيض من فيض، وقطرة من بحر ؛ لأن الإلحاد ببعض معانيها تطلق على كل شالك وضال وملحد غربا وشرقا، 2- الإلحاد بكل نزعاته الفكرية في الغرب هو الذي عبر عنه "نيتشه" حين قال:"لقد مات الله" والإلحاد اليوناني هو الذي يقول:"إن الآلهة المقيمين في المكان المقدس قد ماتو ا" والإلحاد العربي هو الذي يقول: "لقد ماتت فكرة النبوة والأنبياء".

3- الملحدون هم مجموعة منكرين ينتصرون لفكرة هى عدم وجود الله، أو نفي وجوده، متحدين شعوبهم المؤمنة سواء كان شعوبهم مؤمنة مسلمة، أو مسيحية، أو يهودية، أو بوذية، أو أي دين آخر على هذه الفكرة ويعتمد في أساسياته على عدم وجود الله، و إنكار نعيم الجنة، و عقاب النار، في تسيير حياة البشر الذين بؤمنون به، 4- الملحدون في الروح الإسلامية عامة، والعربية خاصة إنما اتجهوا الى فكرة النبوة والأنبياء، وبعضهم تركوا الألو هية، بينما الإلحاد في الحضار ات الأخرى كان يتجه مباثرة إلى التركيز على الألوهية، ولا فارق هنا؛ لأن الحاد بنوعيه كليهما ينفيان الدين، فبإنكار "الإله" عند اليونانيين ينتفي الدين، وبإنكار اللامتناهي عند الغربيين بنتفي الدين، وبإنكار النبوة والأنبياء عند العربي تزول الأديان.

5- الملحدون ينشرون الأفكار الإلحادية، ويقومون بنشر كل فكرة تضعف الثعور العقيدة الدينية، ونزاع الثقة من أهل الدين في كل قطر إسلامي، بل ويستخدمون الدين لهدم الدين، فتورتهم هدم للقديم والمواريت و القيم الدينية جميعها؛ فيلصقون كل عيوب أهل الدين بالدين نفسه.

6- الملحدون يروجون الإلحاد بكل إمكانياتهم المادية والفكرية والمعنوية؛ فبعضهم تحت ستار الإسلام يقضون على أهل الإسلام فيحطمون القيم الدينية الروحية، وإظهار الثك والزيغ، و إثغال الجماهير بشعارات المذاهب اللامذهبية المعاصرة الاشتر اكية والعلمانية الإلحادية، و هذا ما بسير عليه أهل الإلحاد والمعتنقين لفكرة الإلحاد، فيستخدمون كل وسيلة إعلامية و غير إعلامية، وهو ما أدت الى نشر و إطالة الإلحاد برأسه من نوافذ عشه، وهكذا يستمر إلى أن تواجهه الدعوة الصحيحة بالحكمة والموعظة الحسنة، والجدال بالتي هى الأحسن الى هدايتهم ومعرفتهم الطريقة الحقيقية و المستقيمة.

7- القرآن الكريم ينبهنا على وجود هذه الفكرة المتداولة بكل أنواعها و أقسامها الموجودة، والمتعلقة بفكرة إنكار وجود الله تعالى، حيث أن طائفة منهم: ينكرون وجود الخالق الأعظة، وآخرون: يميل عن الحقيقة في أسمائه ـ 
تعالى-، وينسبون إليه ما لا يليق بذاته ـ تعالى-، فيلحدون في آياته، ولا يعترفون بالنبوة والأمور الغيبية، فيضلون

ويضلون

8- القرآن الكريم يرد على الملحدين، ويحذرنا منهم، ويأمرنا بالوقاية من هذه الفكرة، وقد توعّد هؤلاء بالخسران

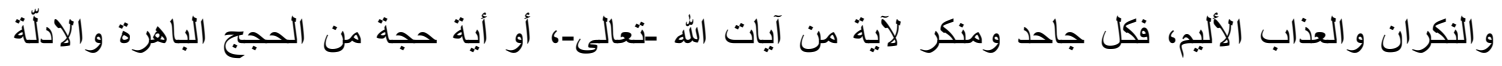

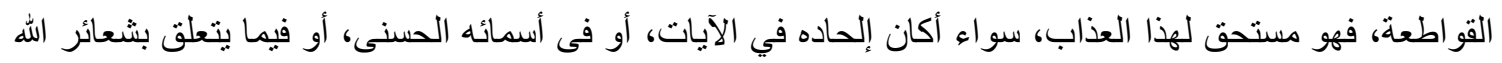
ـ تعالى-؟، فهو يعد خروج وحَيدة عن الحقائق الثابتة عقلا ونقلا، فكل من كفر أو أشرك، أو جحد في الدين يدخل في نطاق معنى للإلحاد الواسع، أما غير ذللك من المؤمن والتقي وكذا التعبد والإنقياد لأوامر الله ـ تعالى-، لا يناله ما يناله أهل الإلحاد و الزندقة.

ونرجو من الله القبول و الامتنان بفضله وكرمه وجوده. وآخر دعوانا أن الحمد لله رب العالمين. 


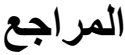 \\ بعد القرآن الكريم}

ابن الجوزي، جمال الدين أبو الفرج عبد الرحمن بن علي بن محمد الجوزي (المنوفى، 597ه)، زاد العسبر في علم التفسير، الطبعة الثالثة، المكتب الإسلامي، بيروت، 1404؛ الضعفاء والمتروكون، ت: عبد الله القاضي، الطبعة الأولى، دار الكتب العلمية، بيروت، 1406.

ابن بطال، أبو الحسن علي بن خلف بن عبد الملك (المتوفى، 449ه)، شرح صحيح البخارى لابن بطال، ت: أبو تميم ياسر بن إبر اهيم، الطبعة الثانية، مكتبة الرشد، الرياض، 1423ه ـ - 2003م.

ابن حجر أبو الفضل العسقلاني، أحمد بن على بن حجر الثنافعي،(المتوفى: 852هـ)، لسان الميزان، الطبعة الثالثة، مؤسسة الأعلمي للمطبوعات، بيروت، 1406 - 1986؛؛ فتح الباري شرح صحيح البخاري، دار المعرفة، بيروت، بدون تناريخ.

ابن حميدو، صالح بن عبد الله، ابن ملوح، و عبد الرحمن بن محمد بن عبد الرحمن، موسوعة نضرة النعيم، في مكارم

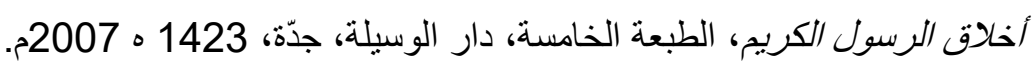

ابن دريد، أبو بكر محمد بن الحسن بن دريد الأزدي (المنوفى، 321ه)، جمهرة اللغة، ت، رمزي منير بعلبكي، الطبعة

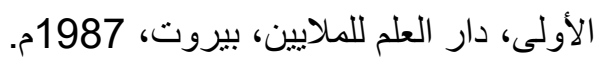

ابن فارس، أبو الحسين أحمد بن زكريا،(المتوفى: 395هـ)، معجم مقاييس اللغة، الطبعة الثنانية، دار الجيل،

$$
\text { بيروت،1420هـ - 1999م. }
$$

ابن كثير،الحافظ عماد الدين أبو الفداء إسماعيل بن عمر بن كثير،(المتوفى: 774هـ)، البد/بة والنهاية، مكتبة المعارف، بيروت.؛ : تفسبر القران العظيم، الطبعة الأولى، بيروت دار نوبلس، تونس، 2006 م.

ابن منظور، محمد بن مكرم بن منظور الأفريقي المصري،(المنوفى: 711هـ)سان العرب، الطبعة الأولى، دار صادر ، بيروت، 1414ه.

أبو الفتح، ناصر الدين بن عبد السيدبن علي بن المطرز،(المتوفى: 610هـ)، المغرب في ترتبب الدعرب، ت: محمود

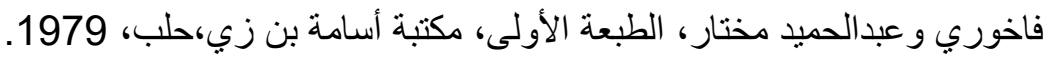
أبو بكر بن أحمد بن محمد بن عمر بن قاضي شهبه،(المتوفي: 851 هـ)طبقات الثافعية، عالم الكتب، بيروت ، الطبعة الأولى 1407.

أبو حبيب، سعدي، القامو الفقهي لغة واصطلاحا، الطبعة الثانية، دار الفكر ، دمثق، سورية ، 1408 ه = 1988 م. أبو حفص، سر اج الدين عمر بن علي بن عادل الحنبلي الدمثقي النعماني (المنوفى، 775ه)، اللباب في علوم الكتاب، المحقق، الثيخ عادل أحمد عبد الموجود والثيخ علي محد معوض، الطبعة الأولى، دار الكتب العلمية، بيروت، لئ، 1419 هـ ـ 
أبو هلال العسكري، أبو هلال الحسن بن عبد الله بن سهل بن سعيد بن يحيى بن مهران العسكري (المتوفى، نحو 395ه)، معجم الفروق اللغوية، ت:: الثيخ بيت الله بيات، ومؤسسة النشر الإسلامي التابعة لجماعة المدرسين ب+ لاقمه الطبعة

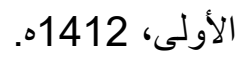

أحمد بن إبر اهيم بن عيسى،(المتوفى: 1327هـ)، توضيح الدقاصد وتصحيح القواعد في شرح قصبة الإمام /بن القيم، الطبعة الثالثة، المكتب الإسلامي، بيروت، 1406.

الأزهري، أبو منصور محمد بن أحمد بن الأزهر الأزهري الهروي،(المتوفى: 370هـ)الزاهر في غريب ألفاظ

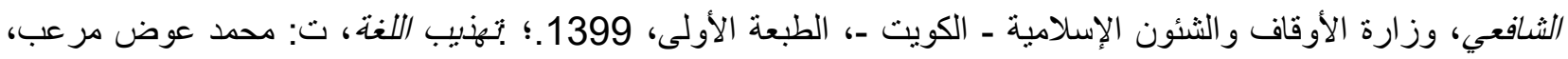
الطبعة الأولى، دار إحياء التراث العربي، بيروت، 2001م، الإنياء الأصفهاني، الر اغب أبو القاسم الحسين بن محمد (المنوفى، 502ه)، الذريعة الى مكارم الثربعة، ت: أبو اليزيد أبو زيد العجمي، دار السلام ، القاهرة، 1428 ه ، 2007 م.؛ : مفردات ألفاظ القران الكريم، الطبعة الأولى، دار القلم ، دمشق ،

الآلوسي، أبو الفضل شهاب الدين السيد محمود الآلوسي البغدادي،(المتوفى: 1270هـ)، روح الدعاني في تفسير القرآن العظبم والسبع الدثاني، دار إحباء التراث العربي، بيروت، بدون تاريخ وطبعة.

البدوي، عبد الرحمن، من تاريخ الإحاد في الإسلام ـ تأليف و ترجمة ـعبد الرحمن بدوي، سينا للنشر، القاهرة الطبعة الثانية ، 1993م.

البهي،محد، الفكر الاسلامي والمجتمع الدعاصر- دار التوفيق النموذجية، القاهرة ، طبعة الثالثة - 1402 ه ـ

البوطى، محمد سعيد رمضان، الاسلام و الغرب، دمثق دار الفكر، طبعة الاول، 2007 م -1428 ه.

البيضاوي، ناصر الدين أبو سعيد عبد الله بن عمر بن محمد الثيرازي (المتوفى، 685ه) تفسير البيضلاوي العسدى بأنوار التنزيل، دار الفكر، بيروت، بدون ناريخ.

التفتاز اني، سعد الدين مسعود بن عمر بن عبد الله الثافعي،(المنوفي: 793 هـ)، شرح العقائد على العقائد النسفبه، الطبعة الأولى، مطبعة الباقري، كوردستان،1374.

التهانوي، محمد بن علي ابن القاضي محمد حامد بن محمّد صابر الفاروقي الحنفي (المنوفى، بعد 1158ه) كثاف اصطلاحات الفنون والعلوم، تقديم وإثر اف ومراجعة،رفيق العجم ت: علي دحروج، نقل النص الفارسي إلى العربية، عبد الله الخالدي الترجمة الأجنبية، د.جورج زيناني، الطبعة الأولى، مكتبة لبنان ناشرون - بيروت، وهئ، 1996م.

الجرجاني، علي بن محمد بن علي، ( 740- 816) التعريفات، تحقيق: إبراهيم الأبياري، دار الكتاب العربي ، بيروت، الذهبي، أبو عبد الله محمد بن أحمد بن عثمان بن قايماز، سبر أعلام النبلاء، الطبعة التاسعة، مؤسسة الرسالة ، بيروت، 
الرازي، زين الدين أبو عبد الله محمد بن أبي بكر بن عبد القادر الحنفي (المتوفى، 666ه) مختار الصحاح، ت: يوسف الثيخ محمد، الطبعة الخامسة، المكتبة العصرية ، بيروت- صيدا، 1420ه / 1999م.

رشيد رضا، محمد بن علي بن محمد شمس الدين بن محمد بهاء الدين بن منلا علي خليفة القلموني الحسيني (المنوفى،

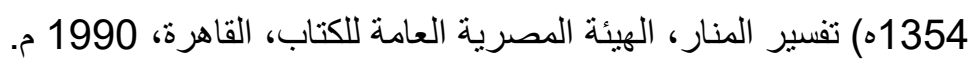
رميس عوض، الإحاد في الغرب، سينا للنشر، بيروت، الطبعة الأولى، 1997م. الزبيدي، الزَّبيدي محمّد بن محمّد بن عبد الرزّاق، أبو الفيض مرتضى الحسيني (المتوفى، 1205ه) تاج العروس من جواهر القاموس، الطبعة الأولى، دار الهداية، بيروت، بدون تاريخ. الزمخشري، أبو القاسم محمود بن عمر الخوارزمي،(المتوفي: 538هـ) الكثاف عن حقائق التنزيل وعبيون الأقاويل في

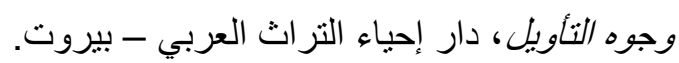
السعدي، عبد الرحمن بن ناصر بن عبد الله (المنوفى، 1376ه) تببسبر الكريم الرحمن في تفسبر كلام الهنان، المحقى، عبد الرحمن بن معلا اللويحق، مؤسسة الرسالة الطبعة الأولى، 1420ه -2000 م.؛ : الأدلة القواطع و البر/هبن في إبطال أصول الملحدبن، الطبعة الأولى، دار النهج، القاهرة، 1423 ه 2003 م.

السمعاني، أبو المظفر منصور بن محمد بن عبد الجبار السمعاني، تفسير القرآن، الطبعة الأولى، دار الوطن، الرياض، 1997 - 1418

سندي، صالح بن العبد العزيز بن عثمان، الإلحاد وسائله وخطره وسبل مواجهته، دار اللؤلؤة-بيروت-لبنان-الطبعة الاولى،2013م.

سيد قطب، في ظلال القران، دار الشرق-بيروت- الطبعة الثرعية،الحادية عشرة، 1405 ه 1985م. السيوطي، عبد الرحمن بن الكمال جلال الدين أبو الفضل (المنوفى، 911ه) لباب النقول في اسباب النزول، دار إحياء العلوم - بيروت. ؛ : الدر المنثور، دار الفكر - بيروت - 1993.

الثنقيطي، محمد الأمين بن محمد بن المختار الجكني الثنقيطي،(المنوفى : 1393هـ) أضواء البيان في إيضاح القرآن بالقرآن، دار الفكر، بيروت،1415هـ - 1995م. الثهرستاني، محمد بن عبد الكريم بن أبي بكر أحمد،(المنوفى: 548هـ) الملل والنحل، تح: محمد سبد كيلاني- دار

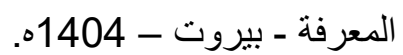

الثوكاني، محمد بن على بن محمد،(المتوفى: 1250هـ) فتح القدبر الجامع بين فني الرواية والدراية من علم التفسير، دار الفكر-بيروت. الصعيب، حسن، الماركسية والدين، دار التنوير، قاهرة، 2009 م. الطبري، أبو جعفر محمد بن جرير بن بزيد بن خالد،(المتوفى: 310هـ) جامع البيان عن تأويل آي القرآن، دار الفكر، بيروت، 1405ه. 
طعيمة، صابر عبد الرحمن، الإحاد الديني في مجتمعات المسلمبن، نشأته وتطوره ومذاهبه الدعاصرة، الطبعة الأولى،

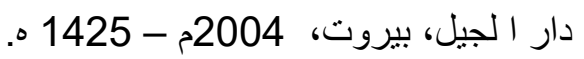

عبد المنعم، محمود عبد الرحمن، معجم المصطلحات والألفاظ الفقعية، دار الفضيلة، القاهرة، بدون تاريخ.. العلايلي، عبد الله العلايلي، الصحاح في اللغة والعلوم، الطبعة الأولى، دار الحضاره العربية،بيروت،1947م. عليان، رشدي محمد؛ وقحطان، عبدالرحمن، أصول الدين الإسلامي، الطبعة الثالثة، بيروت، 2004م. عمر، أحمد مختار عبد الحميد عمر (المتوفى، 1424ه) معجم اللغنة العربية المعاصرة، بمساعدة فريق عمل، عالم الكتب الطبعة الأولى، 1429 هـ - 2008 م.

الفار ابي، أبو نصر إسماعيل بن حماد الجوهري (المتوفى، 393هـ ) الصحاح تاج اللغة وصحاح العربية، تحقيق: أحمد عبد الغفور عطار، الطبعة الرابعة، دار العلم للملايين ، بيروت، 1407 هـ - 1987 م. الفراهيدي، الخليل بن أحمد،(المتوفى: 170هـ) كتاب العبن، دار ومكتبة الهلال، ت: مهدي المخزومي،و إبراهيم

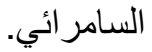

فرغل، يحي هاثم حسن، موسوعة العقبدة والإِيهان الفكر الدعاصر- في ضوء العقبية الإسلامبة- الطبعة الأولى، دار الأفاق العربية ، القاهرة، 2007م.

الفيروزآبادي، محمد بن يعقوب الفيروزآبادي (المنوفى 817 ه) القاموس المحبط، مؤسسة الرسالة، بيروت، بدون تاريخ. الفيومي، أحمد بن محمد بن علي المقري الفيومي،(المنوفى: 770هـ) المصباح المنير في غريب الثرح الكبير للر افعي، المكتبة العلمية-بيروت. القرطبي، أبو عبد الله محمد بن أحمد الأنصاري القرطبي،(المتوفى: 671 هـ) الجامع لأحكام القرآن، دار الثعب، القاهرة، بدون تاريخ وطبعة.. الكفوي، أبو البقاء أيوب بن موسى الحسيني الكفوي،(المتوفى: 1094هـ) كتاب الكلبات، ت: عدنان درويش- محمد المصري، مؤسسة الرسالة ، بيروت ، 1419هـ -1998م. محمد قطب، مذاهب فكرية معاصرة - دار الثروق ـ القاهرة، الطبعة العانرة - 2008. المر اغي، أحمد بن مصطفى (المتوفى، 1371ه) تفسير المراغي، الطبعة الأولى، شركة مكتبة ومطبعة مصطفى البابى الحلبي، القاهرة، 1365 هـ - 1946 م.

مصطفى، إبراهيم الزيات؛ أحمد، عبد القادر؛ حامد النجار، محمد، الدعجم الوسبط، دار الدعوة، ت: مجمع اللغة العربية، القاهرة. الملياني، موسى بن محمد بن الملياني الأحمدي، معجم الأفعال المتعدية بحرف، نسخة المكتبة الثاملة الموافق للمطبوع. 
المناوي، زين الدين محمد المدعو بعبد الرؤوف بن ناج العارفين بن علي بن زين العابدين الحدادي ثم المناوي القاهري

(المتوفى، 1031ه) التوقيف على مهدات التعاريف، عالم الكتب 38 عبد الخالق ثروت-القاهرة الطبعة الأولى، 1410هـ

الموسوعة المبيرة في المذاهب المعاصرة،إثراف وتخطيط ومر اجعة، دار الندوة العالمية للطباعة والنشر والتوزيع

$$
\text { الطبعة الر ابعة، } 1420 \text { هـ } 1420
$$

الميداني، عبد الرحمن حسن حنبكة، أجنحة المكر الثلاثة، وخوافيها، التبشبر، الاستشراف، الاستعدار، الطبعة الأولى،

$$
\text { دار القلم، دمشق، 1414ه 1994م. }
$$

النسفي، أبو البركات عبد الله بن أحمد بن محمود حافظ الدين (المنوفى، 710هـ ) تفسير النسفي، مدارك التنزيل وحقائق التأويل، حققه وخرج أحاديثه، يوسف علي بديوي راجعه وقدم له، محيي الدين ديب مستو، الطبعة الأولى، دار الكلم الطيب، بيروت، 1419 هـ - 1998م.

نصري، هاني يحيي، نقض الإلحاد تحديد/ت وتنبيهات و إيضاحات، الطبعة الأولى، المؤسسة الجامعية للار اسات و النشر و التوزيع ، بيروت، لبنان ، 1420هـ - 2000 م.

نكري، الأحمدي، والقاضي، عبد النبي بن عبد الرسول (المتوفى: ق 12هـ) دستور العلماء أو جامع العلوم في

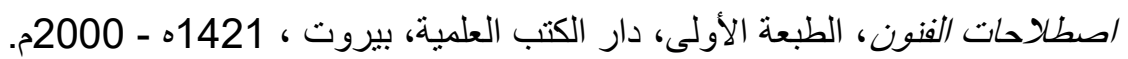

\section{المواقع الالكثرونية : 2}

بقاعين، جريس سالم بقاعين "دراسة تاريخ الإلحاد في الإسلام"، www.ahewar.orgلحوار المتدن-العدد: 1327 


\section{يوخته}

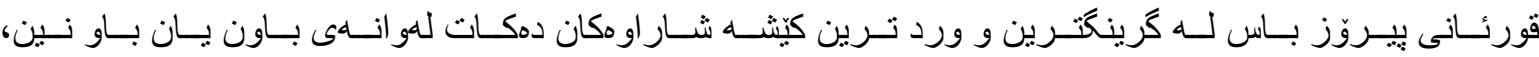

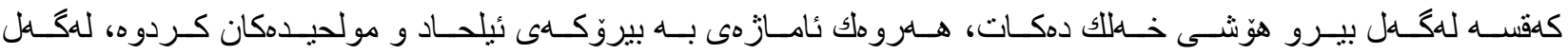

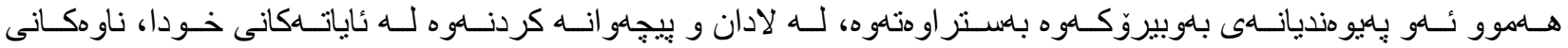

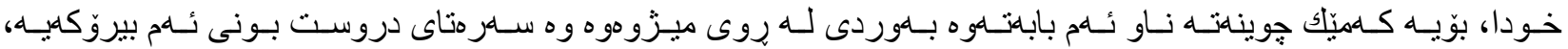

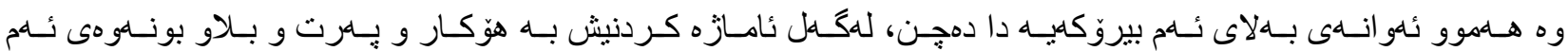

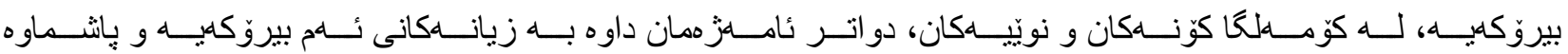

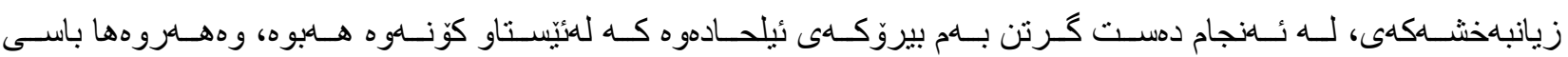

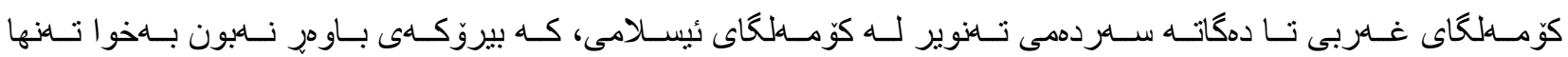

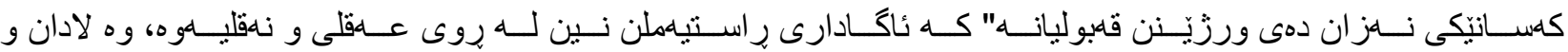

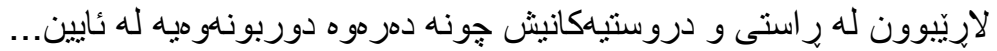




\section{Summary:}

The Qur'an presented the most important issues and confirmed them in the field of religious belief; addressing people's hearts and minds, referring to the idea of atheism and atheists; with regard to both atheism and deviation from the verses of Allah, and atheism in its names; The emergence of these ideas and their spread in the midst of atheistic tendencies, and the signs of these currents in their orbit smell of atheism, highlighting how these ideas originate and the causes of maturity, and its spread in ancient and modern societies, with reference to the damage of atheism and its negative effects on people, The discussion of atheism in Western societies in the Dark Ages until the Age of Enlightenment and the Islamic community, where the denial of the existence of God is accepted by some fools who are ignorant of the fixed truth and reason, And the departure from reasonable purposes heresy, atheism and out of religion, and this is the goal of research. 